\title{
REGIONAL SCALE MODELING OF HILLSLOPE SEDIMENT \\ DELIVERY: A CASE STUDY IN THE BARASONA RESERVOIR WATERSHED (SPAIN) USING WATEM/SEDEM
}

\author{
L.C. Alatorre $^{1 *}$, S. Beguería ${ }^{2}$, J.M. García-Ruiz ${ }^{1}$ \\ ${ }^{1}$ Instituto Pirenaico de Ecología (CSIC), Zaragoza (Spain). \\ ${ }^{2}$ Estación Experimental de Aula Dei (CSIC), Zaragoza (Spain).
}

* Corresponding author address: Instituto Pirenaico de Ecología (CSIC), Avda. Montañana 1005, 50059 - Zaragoza (Spain). PO Box 13034, 50080 - Zaragoza (Spain). Tel: +34 976716 156; Fax: +34 976716 019; E-mail: lalatorre@ipe.csic.es

\begin{abstract}
Soil erosion and sediment delivery to streams are important environmental problems and major concerns in sustainable development. In recent years several tools have been proposed for assessing the delivery of sediment from hillslopes to stream networks, but there are still few examples of their application to large basins, and studies include a discussion of calibration and validation issues. In this study a spatially distributed soil erosion and sediment delivery model (WATEM/SEDEM) was applied to the watershed of the Barasona Reservoir (1,504 $\mathrm{km}^{2}$, Central Spanish Pyrenees), which is drained by the Ésera and Isábena rivers. Model calibration and validation was based on the depositional history of the Barasona Reservoir and suspended sediment records over 3 years (May
\end{abstract}


2005 to May 2008) at the outlet of the Isábena River. Despite interannual differences in precipitation and runoff, it was possible to establish an optimum value (7-23) for the ktc parameter. This enabled estimation of the long-term average annual sediment yield to the reservoir, as well as the relative contribution of each river. Large spatial variability in hillslope sediment delivery was found, and the major sediment sources were in the lower part of the watershed (agricultural fields) and in the badlands developed on Eocene marls in the middle part of the watershed (Pyrenean Inner Ranges). The relative importance of sediment source areas was assessed in relation to land use, and the relationship between the sediment delivery ratio and the catchment area was studied as a function of the geomorphological units. For the moment WATEM/SEDEM remains mainly as a researcher's tool, until either the problem of the scarcity of soil erosion data or the need for calibration of the transport parameters will be solved.

Keywords: soil erosion, sediment yield, reservoir sedimentation, sediment delivery ratio, sediment sources 


\section{Introduction}

Soil erosion and sediment yield to streams are geomorphological processes exacerbated by land degradation, and constitute significant environmental conservation threats because of the areal extent typically involved. Estimates indicate that one-sixth of the global land area is affected by accelerated water erosion (Schröter et al., 2005). Soil erosion is a natural process that can be strongly accelerated by land use and climate change, representing an important hazard to the long-term sustainability of agriculture and ecosystem services. Therefore, erosion and is receiving increasing attention from local, national, transnational, and global policy makers (e.g., UN, 1994; EC, 2002; COST634, 2005). To develop environmental and land use management plans policy makers require quantification of erosion rates at regional and global scales, and for various sediment sources, allowing erosion prevention efforts to be concentrated in places where the benefit will be greatest (de Vente et al., 2008). Erosion and sediment production is thus of both theoretical and practical interest.

Although most erosion and sediment deposition processes have been studied in detail, modeling of the link between on-site soil erosion and total sediment yield at the outlet of a catchment is often problematic because of the difficulties associated with modeling of a cascading system, and also because of the lack of detailed input data at regional scales $\left(100-10,000 \mathrm{~km}^{2}\right)$. Regional scale soil erosion maps must be used with caution, as it is difficult to make well-founded policy decisions based on such maps if there are no reliable estimates of errors in predicted erosion and sediment yield rates. A direct comparison of the predicted erosion rates with field observations, which is necessary for quantifying the accuracy of estimates, is usually not possible because it is 
not practically or financially feasible to acquire long-term, spatially distributed soil erosion data. In the best instances, data are available only on the sediment transported by the main rivers in a catchment, and these data seldom span a long time period. An alternative approach is the use of sedimentation records in lakes and reservoirs. The mean annual sediment volume trapped in reservoirs can be measured, providing valuable sediment flux information at regional scales (the size of the contributing area) and over long periods (since the year of construction or last cleaning of the reservoir). However, not all eroded sediment reaches the outlet of a drainage basin, as a significant proportion is typically deposited at intermediate locations depending on the drainage density, the spatial configuration of the relief, and the land cover. Assessment of this aspect requires a basic understanding of the spatial patterns, rates, and processes of sediment transport on a regional scale.

Most regional erosion models do not consider the spatial variability of sediment supply to streams. In some cases an average erosion rate is estimated for an entire catchment using the universal soil loss equation (USLE, Wischmeier and Smith, 1978) or its revised version (RUSLE, Renard et al., 1991) in conjunction with a sediment delivery ratio (SDR) parameter to determine the sediment supply from the hillslopes to the streams (e.g., Williams, 1975; Arnold et al., 1998). The use of the SDR parameter accounts for the well-known fact that most of the sediment generated by soil erosion gets deposited within the watershed, and only a fraction of it will reach the stream system to be evacuated through the watershed outlet. Many empirical regression equations have been developed to predict the SDR from hillslopes to streams based on the catchment area alone (e.g., Roehl, 1962; Vanoni, 1975; Walling, 1983; Ferro and Minacapilli, 1995). 
Recent advances in numerical modeling and the availability of spatial data on land use, soils, topography, and climate have enabled soil erosion maps of high spatial resolution to be constructed at regional scales, mostly using an USLE/RUSLE approach (e.g. Jäger, 1994; Van der Knijff et al., 2000; Van Rompaey et al., 2000; Lu et al., 2001). A very simple method based on a fixed sediment delivery ratio is used to calculate the proportion of eroded sediment delivered to the stream network (e.g., Prosser et al., 2001). However, this approach does not consider the spatial variability in sediment delivery processes. It has been shown that the SDR is not homogenous across a watershed, but varies with changes in watershed area and slope (Osterkamp and Toy, 1997).

WATEM/SEDEM is a spatially-distributed erosion and sediment transport model based on the RUSLE equation. The model predicts sediment delivery to streams using a sediment transport capacity equation and a cascading transport model (Van Rompaey et al., 2001a). WATEM/SEDEM has been applied to catchments representing a wide range of environmental conditions; these include the cultivated loess areas of central Belgium (Van Rompaey et al., 2001a; Verstraeten et al., 2002); hilly areas of the Czech Republic (Van Rompaey et al., 2003a); a variety of ecosystems in Italy (Van Rompaey et al., 2005); and forested mountain areas in South Africa (Van Rompaey et al., 2003b). Using data on reservoir sedimentation rates from 61 Spanish catchments, de Vente and colleagues (2008) compared three spatially distributed models of soil erosion and sediment yield: WATEM/SEDEM, the physically based Pan-European soil erosion risk assessment (PESERA), and a newly developed spatially distributed scoring model (SPADS). SPADS and WATEM/SEDEM produced the best results, explaining up to $67 \%$ and $47 \%$ of the variation in sediment yield, respectively. The ability of 
WATEM/SEDEM to model hillslope sediment yield to streams at the regional scale using shuttle radar topography mission digital topographic map (SRTM DTM) data was assessed by Verstraeten (2006). These and other applications suggest that WATEM/SEDEM is a valid tool for assessing spatial patterns of erosion and sediment flux on the landscape. However, some questions of the model's appliction still arise, such as the need for a spatially distributed calibration (Takken et al., 1999, 2005; Vigiak, 2006) or the importance of processes not included in the model (de Vente et al., 2008).

The main objective of the present study was to assess soil erosion and sediment yield in a mountain basin using typically available data such as a digital terrain model (DTM), land cover/land use maps, and bathymetrical data on the long-term sediment yield. The Ésera River basin was selected for the case study because of the importance of the Barasona Reservoir and the availability of previous research findings on the depositional history of the reservoir. We describe the compromises adopted in calibrating the model, and discuss the validity of the results and their applications.

\section{Materials and methods}

\subsection{Hillslope sediment delivery model}

WATEM/SEDEM was used to estimate the sediment flux from hillslopes to the stream network in the Barasona Reservoir catchment. A detailed description of the model has been provided by Van Oost et al. (2000), Van Rompaey et al. (2001a) and Verstraeten et al. (2002); in this report only the basic principles are described. 
WATEM/SEDEM is a grid-based model that uses IDRISI GIS raster layers as input. In the first step the model calculates (equation 1) the annual soil erosion per grid cell, based on a 2D application of the RUSLE model (Renard et al., 1991):

$E=R K L S_{2 D} C P$,

where $E$ is the mean annual soil loss $\left(\mathrm{kg} \mathrm{m}^{-2} \mathrm{y}^{-1}\right), R$ is a rainfall erosivity factor (MJ $\mathrm{mm}$ $\left.\mathrm{m}^{-2} \mathrm{~h}^{-1} \mathrm{yr}^{-1}\right), K$ is a soil erodibility factor $\left(\mathrm{kg} \mathrm{h} \mathrm{MJ}^{-1} \mathrm{~mm}^{-1}\right), L S_{2 D}$ is a slope-length factor (Desmet and Govers, 1996) to account for flow convergence in a complex topography of 2D landscape, $C$ is a dimensionless crop management factor, and $P$ is a dimensionless erosion control practice factor.

In the second step the generated sediment is routed down the slope until a stream cell is reached. Sediment on the hillslopes is assumed to be transported by the overland flow, according to the transport capacity equation (equation 2; Van Rompaey et al., 2001a):

$T C=k t c R K\left(L S_{2 D}-4.1 s^{0.8}\right)$,

where $T C$ is the transport capacity $\left(\mathrm{kg} \mathrm{m}^{-1} \mathrm{yr}^{-1}\right), k t c(\mathrm{~m})$ is an empirical transport capacity coefficient that depends on the land cover, and $s$ is the slope gradient $\left(\mathrm{m} \mathrm{m}^{-1}\right)$. For each grid cell a mass balance is computed, and the sediment input plus the sediment generated at the cell is either routed down slope (if it is lower than the transport capacity) or deposited (if it is greater than the transport capacity). Alternative formulations of the transport capacity exist. For example, Verstraeten et al. (2007) proposed a different equation for $T C$, devised for environments where gully erosion is dominant. We used the original formulation as implemented in the WATEM/SEDEM 2004 software. 
The transport capacity parameter, ktc, represents the slope length needed to produce an amount of sediment equal to a bare surface with an identical slope gradient (Verstraeten, 2006). The ktc parameter is dependent on the land cover, and in previous applications of the model a distinction has usually been made between arable land (highly prone to erosion) and land not prone to erosion, including forests and pastures (Van Rompaey et al., 2001a, 2005; Verstraeten et al., 2007). It is also scale-dependent (i.e., it depends on the grid cell size) and needs to be calibrated for each application of the model.

WATEM/SEDEM does not model permanent gully erosion nor fluvial transport processes (such as river bank erosion, floodplain sedimentation and channel storage), so all sediment in the model is directly delivered to the outlet of the catchment as soon as it reaches a stream cell (Verstraeten and Prosser, 2008). Hence, sediment source and deposition areas within the stream network are ignored when computing the catchment sediment budget. Although the model is capable of identifying major sediment source areas on hillslopes and can estimate the relative contribution to the overall sediment budget of individual sub-catchments and different land units, ignoring stream processes can introduce a bias during model calibration in catchments where these processes are important.

\subsection{Study area and data used}

\subsubsection{The Ésera River basin}

The study area is drained by two major rivers: the Ésera River and its major tributary, the Isábena River (Fig. 1). The river catchments cover an area of $1504 \mathrm{~km}^{2}$ 
(1066 $\mathrm{km}^{2}$ and $438 \mathrm{~km}^{2}$, respectively) in the Central Spanish Pyrenees, and are located in the Ebro basin between $42^{\circ} 3^{\prime} \mathrm{N}, 0^{\circ} 16^{\prime} \mathrm{W}$ and $42^{\circ} 42^{\prime} \mathrm{N}, 0^{\circ} 42^{\prime} \mathrm{W}$. Part of the headwater $\left(12.9 \mathrm{~km}^{2}\right)$ was discounted as effective drainage area because it drains by a subterranean route through Devonian limestone karst to the Garona River, on the Atlantic (northern) side of the Pyrenees; this represents an average discharge loss of about $3 \mathrm{~m}^{3} \mathrm{~s}^{-1}$ from the Ésera River (López-Moreno et al., 2002). The basin formed by the Ésera and Isábena rivers is characterized by heterogeneous relief, vegetation and soils. Elevation ranges from $450 \mathrm{~m}$ asl in the southern and central parts to $3,404 \mathrm{~m}$ asl in the Ésera subcatchment and 2,720 $\mathrm{m}$ asl in the Isábena subcatchment, in the northern part (Fig. 2A).

The lithology of the area (Fig. 2B) comprises geological structures organized in several units trending WNW-ESE : (i) the axial zone of the Pyrenees (Axial Pyrenees), composed of Paleozoic rocks (quartzites, limestone, shales) and granodiorites with peaks above 3,000 m asl; (ii) the Inner Ranges, which is a huge overthrusting fold of Cretaceous and Paleogene sediments composed mainly of limestones and sandstones, which results in a craggy relief; (iii) the Inner Depressions (Campo), which is formed on more erodible materials (marls) giving a relatively smooth relief; (iv) the prePyrenean molasses, which are composed of continental Oligocene sediments (conglomerates, sandstones) giving an abrupt relief and smooth divides; and (v) the External Ranges, which are composed of limestone and bound the basin to the south.

The soil types (Fig. 2C; based on Machín, 1990) reflect the importance of mineral soils with little development (including regosols, leptosols and fluvisols; 53\% of the area) and soils with a noticeable accumulation of organic matter, including kastanosems (32\% of the area). Other soil types are poorly represented in the study area. 
The climate is typical of mountain areas; it is wet and cold from Atlantic and Mediterranean influences (García-Ruíz et al., 2001), and has strong north-south gradients. The average annual precipitation and temperature range (respectively) from more than $2000 \mathrm{~mm} \mathrm{yr}^{1}$ and $4{ }^{\circ} \mathrm{C}$ in the headwaters to less than $500 \mathrm{~mm} \mathrm{yr}{ }^{1}$ and $12^{\circ} \mathrm{C}$ at the Barasona Reservoir. Late spring (May-June) and autumn (November), followed by summer are the wettest periods. Storms are common, with the most intense usually occurring in summer and autumn. For example, in the Ésera River headwaters more than $200 \mathrm{~mm}$ of rainfall in $24 \mathrm{~h}$ is expected for a 100 year return period (Chueca and Julián, 2002). Snow covers the soil above $1700 \mathrm{~m}$ asl from mid November to May (Del Barrio et al., 1990), and the greatest river discharges tend to occur in May-June, and occasionally in autumn (López-Moreno and García-Ruiz, 2004).

Based on the land use/land cover map (Fig. 2D; CLC, 2000) the area comprises scrubland and grassland (36\%), forests (32\%), fields under agriculture (16\%), areas with little or no vegetation $(14 \%)$, water bodies $(<1 \%)$, and infrastructure and built-up areas $(<1 \%)$.

\subsubsection{The Barasona Reservoir}

The Barasona Reservoir, close to the mouth of the Ésera River, was built in 1932 for irrigation and power generation (Fig. 1). The initial water capacity was $71 \times 10^{6} \mathrm{~m}^{3}$. In 1972 the height of the dam was increased and the maximum storage capacity reached $92 \times 10^{6} \mathrm{~m}^{3}$. The reservoir has a surface area of approximately 692 ha, a maximum depth of $60 \mathrm{~m}$, and an average depth of $16.5 \mathrm{~m}$. The installed capacity of the power station is 26 MW. The Aragón and Cataluña canal originates in the reservoir and provides irrigation 
water to 104,850 ha of arable land. The irrigation season extends from March to October, with maximum demand occurring from May to August. At the end of the irrigation season, prior to the autumn and winter rainfall, the reservoir water level is typically low enough to expose the bottom sediments over large areas (see photograph, Fig. 1). Over the past 65 years there has been a considerable loss of storage capacity in the reservoir (e.g. Avendaño et al., 1997a, 1997b; Navas et al., 1998; Valero-Garcés et al., 1999). Until the early 1950s the reservoir was drained every year from bottom outlets, which resulted in most of the deposited sediments being flushed out because of the kinetic energy provided by the inflowing river water (Ebro Water Authority - CHE technicians, personal communication). After the 1950 s the operational management regime changed due to malfunctions in the bottom outlets, so they were not operated. A seismic survey in 1995 indicated that the reservoir had lost approximately one-third of its initial water storage capacity; the volume of accumulated sediment in the reservoir was about $16-18 \times 10^{6} \mathrm{~m}^{3}$, with a maximum thickness of 20-25 m near the dam wall (Sanz Montero et al., 1996). After years of reservoir siltation the bottom outlets had become plugged. They were replaced in an operation that involved the complete drawdown of the reservoir after the irrigation season over three consecutive years (1995-1998). Limited sediment removal was done during these years mechanically dredging the sediments near the dam wall. However, most of the accumulated sediment was not affected by these operations. Sanz Montero et al. (1996) used bathymetric techniques to obtain an estimate of $3.50 \mathrm{Mg} \mathrm{ha}^{1}$ $\mathrm{yr}^{1}$ for the specific sediment yield of the Barasona watershed (Table 1), a value within the range for other reservoirs in the Pyrenees. 


\subsubsection{Model inputs}

The input data required to run the WATEM/SEDEM model were supplied in the form of IDRISI GIS raster layers (Clark Labs Inc.), each with which identical resolution and spatial coverage. For this study we used a spatial resolution of $20 \times 20 \mathrm{~m}$, based on the recommendation of Van Rompaey et al. (2001a). The input data layers were a digital terrain model (DTM), a drainage network map, a land use map, a rainfall erosivity map, a soil erodibility map, and a crop management map.

The DTM plays a central role in WATEM/SEDEM. It is used to calculate the slope gradient and the length-slope factor $\left(\mathrm{LS}_{2 \mathrm{D}}\right)$, and for routing the sediment downstream. We used a DTM with a spatial resolution of $1 \mathrm{~m}$ elaborated by the Spanish Ministry of Agriculture using photogrammetric restitution. The grid resolution of the DTM was then reduced to the $20 \times 20 \mathrm{~m}$ grid by averaging the values on the original grid. A pit-filling algorithm (Planchon and Darboux, 2001) was used to guarantee the hydrological connectivity to the watershed outlet among all pixels of the DTM.

A map of the stream network was generated using the RUNOFF module in IDRISI, with the assumption that an upstream catchment area greater than $1 \mathrm{~km}^{2}$ defined a channel. The $1 \mathrm{~km}^{2}$ threshold represents an upper limit beyond which sediment deposition is highly unlikely because of concentrated overland flow (Verstraeten et al., 2007). The use of this value generated a river channel network that closely matched the drainage network coverage at the 1:50,000 scale, which was provided by the Hydrographic Confederation of the Ebro River (Fig. 3).

The land use/land cover map was a reclassification of the CORINE 2000 Project land cover data (Fig. 4A). This dataset has a spatial resolution of $100 \times 100 \mathrm{~m}$ and is 
divided into 46 thematic categories. The categories were grouped into five major classes: cultivated land, forest, grassland, infrastructure and built-up areas, and water bodies. The original map was resampled to match the spatial resolution used in the study, using the RESAMPLE algorithm implemented in IDRISI.

The soil erodibility factor (K-factor of the RUSLE model) describes the susceptibility of soil to erosion by rainfall. Because of the lack of detailed soil maps it was necessary to analyze soil samples from the study area. A total of 76 sites generally encompassing the spatial variability of soil types/land cover combinations were sampled in triplicate. The K-factor values were determined from soil texture data (Römkens et al., 1987) according to equation 3 :

$K_{\text {text }}=0.0034+0.0405 \exp \left[-0.5\left(\frac{\log D_{g}+1.659}{0.71}\right)^{2}\right]$,

where $K_{\text {text }}$ is a soil erodibility factor $\left(\mathrm{Mg} \mathrm{h} \mathrm{MJ}{ }^{1} \mathrm{~mm}^{-1}\right)$ and $D_{g}$ is the geometric mean weight diameter of the primary soil particles (fraction $<2 \mathrm{~mm}$ ). $D_{g}$ was determined using a Coulter laser diffraction particle size analyzer (Coulter LS 230) for the 2-2000 $\mu \mathrm{m}$ fraction, following removal of organic matter. The K-factor values were then corrected to reflect the effect of stones in the soil surface on soil erodibility (Box, 1981), according to equation 4:

$K=K_{\text {text }} \exp ^{(-0.0278 S t)}$,

where $S t$ is the weight of stones in the topsoil, expressed as a percentage of the total weight of the topsoil. Soils on the steeper slopes of the Barasona Reservoir watershed are relatively shallow, and hence the potential for erosion on these slopes is lower. Few field data were available to use equation 4, but a field survey based on 228 observations 
showed that stoniness was related to a large extent to the slope gradient, so in most cases slopes steeper than $20 \%$ had a stone cover higher than $25 \%$. Following this observation, we accounted for stoniness by halving the K-factor of those slopes with a gradient exceeding 20\% (Fig. 4B). The resulting K-factor map (Fig. 4B) is conservative, as many of the steeper slopes in the Barasona Reservoir watershed are almost devoid of topsoil, and hence erosion is minimal. The steepest slopes often consist of bare rock (i.e. K-factor $=0)$.

The rainfall erosivity factor (R-factor) is used to represent the impact of rain on soil erosion, and is based on the rainfall amount and intensity. Maps of R-factor values were implemented for the area using a database of 12 selected rainfall series from the SAIH system (automatic hydrological information network) of the Hydrographic Confederation of the Ebro River (Fig. 1). Each station provides precipitation data at a time resolution of $15 \mathrm{~min}$. The system started in January 1997 and is the only dense network in the region providing data at a subdaily resolution. We used all available data series to calculate R-factor values for the periods May 2005 to May 2006, May 2006 to May 2007 and May 2007 to May 2008. For the period 1955-2008, coinciding with the depositional history of the Barasona Reservoir, no high time resolution data were available, so we used an approximation based on daily rainfall data (Angulo-Martínez et al., 2009; Angulo-Martínez and Beguería, 2009). The rainfall erosivity indices used were the RUSLE R-factor (Brown and Foster, 1987) and the average EI30 index. The latter complements the information provided by the R-factor, as it is more influenced by the greatest erosivity events. R-factor maps for the study area (Fig. 4C) were derived from the 12 selected rainfall series point estimations using the smoothing splines method 
(Angulo-Martínez et al., 2009). We did not use an R-equivalent factor for considering the effect of snow melt, as this process is only relevant in the highest parts of the catchment, which are mostly covered by bare rock or debris.

A crop management factor (C-factor) was used to define the susceptibility of various land uses and covers to erosion by water. C-factor values were applied to each land use category according to the values proposed by the Spanish Institute for Nature Conservation (ICONA; Almorox et al., 1994): 0 for water and urban land uses (i.e. no erosion); $0.010-0.300$ for forest land cover; $0.080-0.200$ for scrubland; $0.045-0.150$ for pasture; $0.100-0.400$ for arable land; and $0.166-0.800$ for bare soil categories (for more details see Table 2). A C-factor map was constructed by applying those values to the land uses defined by the CORINE land cover map (CLC, 2000; Fig. 4D).

\subsection{Model calibration}

WATEM/SEDEM requires calibration of the maximum $\left(k t c_{\max }\right)$ and minimum $\left(k t c_{\min }\right)$ values of the transport capacity coefficient for soil under cultivation and a dense forest cover, respectively. It has been suggested (Verstraeten, 2006) that the ratio between these parameters should be kept constant during the calibration process, which has the effect of aggregation into one parameter. Calibration is usually performed using data on sediment yield at the catchment outlet. The original model was calibrated using observed data on sediment yield from 21 catchments in southern Flanders in Belgium (Van Rompaey et al., 2001a; Verstraeten and Poesen, 2001), from which values of $42 \mathrm{~m}$ for nonarable land and $75 \mathrm{~m}$ for cultivated fields were obtained. In a more recent case study values of $75 \mathrm{~m}$ and $250 \mathrm{~m}$ were obtained for the same surface types (Verstraeten et al., 
2006). It is not surprising that $k t c$ values are so variable, as Van Rompaey et al. (2001a) pointed out that a combined erosion-transport model can only be calibrated for a specific combination of grid size and routing method. The use of different routing methods and/or grid sizes results in different calibration values.

Calibration of the $k t c_{\max } / k t c_{\min }$ for the Ésera-Isábena watershed was performed for the three-year period May 2005 to May 2008 using suspended sediment records from the Capella gauge station (López-Tarason et al., 2009), located at the outlet of the Isábena River (Table 1). The R-factor was computed for each of the three years $(937,2180$ and $1900 \mathrm{MJ} \mathrm{mm} \mathrm{ha-}{ }^{1} \mathrm{~h}^{-1}$, respectively) from available rainfall data. The annual sediment yield of the Isábena River was then computed by modifying the values of $k t c_{\max }$ and $k t c_{\min }$ at discrete steps among predefined values. For each combination of $k t c_{\max }$ and $k t c_{\min }$ a sediment yield value was predicted for each year, allowing comparison of the values predicted by WATEM/SEDEM with those measured at the gauge station. The NashSutcliffe model efficiency statistic NS (Nash and Sutcliffe, 1970) was used as a measure of likelihood according to equation 5:

$N S=1-\frac{\sum_{i=1}^{n}\left(O_{i}-P_{i}\right)^{2}}{\sum_{i=1}^{n}\left(O_{i}-O_{\text {mean }}\right)^{2}}$,

where $n$ is the number of observations, $O_{i}$ is the observed value, $O_{\text {mean }}$ is the mean observed value, and $P_{i}$ is the predicted value. $N S$ can range from $-\infty$ to 1 , and represents the proportion of the initial variance accounted for by the model. The closer the value of $N S$ is to 1 , the more efficient is the model. Additionally, the relative root mean square error (RRMSE) was used as an estimate of the model accuracy according to equation 6. 
$R R M S E=1-\frac{\sqrt{\frac{1}{n} \sum_{i=1}^{n}}\left(O_{i}-P_{i}\right)^{2}}{\frac{1}{n} \sum_{i=1}^{n} O_{i}}$

Both $N S$ and RRMSE were calculated for the total sediment yield (SY; $\left.\mathrm{Mg} \mathrm{yr}^{1}\right)$ and the area-specific sediment yield (SSY; $\mathrm{Mg} \mathrm{ha}^{-1} \mathrm{yr}^{-1}$ ).

In using annual sediment yield data we were extending the application of the model, as WATEM/SEDEM was intended for calculation of the long-term mean annual soil erosion rate and sediment export, and not for a specific year or event. In fact, our approach represents estimating the mean annual sediment yield from only three years of data, which is quite short a period, considering that sediment transport by streams often exhibits large interannual variation, as does annual discharge. However, we choose to use the data on annual sediment yield due to i) the fact that these were measured data, and not a bold estimation of sediment yield from more indirect sources such as a bathymetric survey, and ii) the applied interest in checking whether annual sediment data, despite of a short record, could be used for obtaining a reliable calibration of WATEM/SEDEM. The use of annual sediment yield data, in addition, allowed us to reserve the long-term (19551995) sediment deposition record from a reservoir bathymetric survey for validating the model predictions (see next section).

\subsection{Application to the Barasona watershed and model validation.}

Using the $k t c_{\max }$ and $k t c_{\min }$ values obtained from calibration for the Isábena River subcatchment, the model was applied to the entire Barasona watershed. This enabled comparison of the values predicted by the model between the sediment yields of the two 
river basins during the calibration period (relative contribution of each river basin), and between the long-term sediment yield to the reservoir and the depositional history in the Barasona Reservoir. The model results were also used to determine the major sediment sources within the Barasona watershed in relation to land use, and the geological and morphological setting.

\section{Results and discussion}

\subsection{Model calibration}

The results of the calibration process using 3 years of sediment yield data at the outlet of the Isábena catchment are shown in Figure 5. The 2D goodness-of-fit plots clearly show the problems encountered when attempting to calibrate two parameters with only one variable: it is not possible to find a single set of parameters that optimizes the error function. Instead, there is a range of possible parameter combinations that yield equally good results, represented as a 'valley' in the RRMSE plot or a 'ridge' in the NS plot. In the case of the Isábena River we employed data from each of 3 years, which can be considered to be experimental replications, but this did not affect the difficulty associated with calibrating two parameters using data on only one variable (the sediment yield at the catchment outlet).

For the situation shown in Figure 5 it is advisable to transform the optimization problem into a one-dimensional problem by combining both parameters into one, for example by fixing a constant ratio between the parameters; this was the approach we took in this study, as also used by many others who also employed WATEM/SEDEM. However, this introduces an additional problem because there are an infinite number of 
equally valid ratios between $k t c_{\min }$ and $k t c_{\max }$. Differences between these parameter combinations would be restricted to the relative contributions of different land cover types (i.e., the differences in sediment yield among land cover types would become greater as the ratio between the parameters increased), but the final sediment yield at the catchment outlet would remain the same. In other words, the fact that sediment yield at the catchment outlet is accurately predicted does not mean that also the spatial patterns of erosion and sediment fluxes are accurately predicted, so the results obtained must be taken with care. Here we used the ratio 1:3.33, which is in the range of typical values used in other areas: i) 1:3.33 in central Belgium (Verstraeten et al., 2006; Verstraeten, 2006); values ranging between 1:3.80 and 1:2.20 for mountainous and non-mountainous areas in Italy (Van Rompaey et al., 2005); iii) 1:3.89 for seven small catchments in South-Africa (Van Romapey et al., 2001b; Verstraeten et al., 2001); iv) 1:2.50 for the Czech Republic (Van Rompaey et al, 2003a); and v) 1:3.33 for the south-western part of Slovenia (Keestra et al., 2009). Other authors, however, came up with values as high as 1:1.79 (Van Rompaey, 2001a).

By adopting a fixed ratio of 1:3.33 between $k t c_{\min }$ and $k t c_{\max }$ it was possible to derive a single best-parameter set, which corresponded to $7 \mathrm{~m}$ and $23 \mathrm{~m}$, respectively (Fig. 6). These values coincide with those obtained for calibration in a large watershed in the Scheldt River (Verstraeten, 2006). The results of simulation in the Isábena catchment using these values are shown in Table 3. Despite differences in the amount of precipitation and runoff in the 3 years of the calibration period, the simulated values of SY and SSY were very close to observed values. 
However, it is clear that calibration of the transport capacity parameters is a very important issue of WATEM/SEDEM that has yet to be adequately solved, so further research is needed to address the uncertainties involved. It seems clear that, for getting reliable estimation of spatial erosion and sediment transport patterns a spatially distributed validation is required, as it has been suggested by some authors (Takken et al 1999, 2005; Vigiak 2006).

\subsection{Regional scale hillslope sediment delivery}

\subsubsection{Relative contribution of each river basin}

Application of the calibrated parameter set to the entire Barasona watershed (Ésera and Isábena rivers) for the 3 calibration years allowed estimation of the total sediment yield to the reservoir during that period, and assessment of the relative contributions of each sub-catchment (Table 4). The SY for the period May 2005 to May $2006\left(0.4 \times 10^{6} \mathrm{Mg} \mathrm{year}^{1}\right)$ was $50 \%$ lower than for the other 2 years, and the SSY $(2.69$ $\mathrm{Mg} \mathrm{ha}^{-1}$ year $^{1}$ ) was $24 \%$ lower than the average estimated from a bathymetric survey in the Barasona Reservoir (3.50 Mg ha ${ }^{1}$ year ${ }^{1}$; Sanz-Montero et al., 1996). These differences can be attributed to the average annual runoff and precipitation for the period May 2005 to May $2006\left(674 \mathrm{hm}^{3}\right.$ and $824 \mathrm{~mm}$, respectively). The value for average annual runoff was lower than the long-term average for the period $1955-2008\left(755 \mathrm{hm}^{3}\right.$ year ${ }^{1} ; \sigma= \pm 298 \mathrm{~mm} \mathrm{year}^{-1}$ ), and for precipitation was lower than the long-term average for the period 1970-2008 (870 mm year $\left.{ }^{1} ; \sigma= \pm 311 \mathrm{~mm} \mathrm{year}^{1}\right)$ (Fig. 7). The R-factor for the period May 2005 to May 2006 was also the lowest registered in the 3 years. 
In contrast the SSY predicted for the latter 2 years (May 2006 to May 2008) was approximately $60 \%$ higher than the long-term average $\left(3.50 \mathrm{Mg} \mathrm{ha}^{-1}\right.$ year $\left.^{1}\right)$. This difference cannot be explained by the runoff recorded in this period $\left(766 \mathrm{hm}^{3}\right.$ year $\left.{ }^{1}\right)$, which was similar to the long-term average for the period 1955-2008 (Fig. 7). However, precipitation $\left(1,162 \mathrm{~mm}\right.$ year $\left.^{1}\right)$ was significantly higher than the long-term average for the period 1970-2008 (Fig. 7), as were the R-factor values. For the entire period the runoff time series matched the time series of annual precipitation quite well, with the exception of some anomalous years in which the annual runoff was lower than average despite a high precipitation record (e.g., 1979, 1992, 1999, 2000, 2007, and 2008; Fig. 7). We observed that in all such cases these years were preceded by 1 or more years with very low precipitation. A mechanism possibly explaining this multi-annual behavior of runoff is deep aquifer recharge, which occurs at a much slower rate than other processes of the catchment hydrological cycle. However, we lacked the data to prove this hypothesis.

The results suggest that a small increase in annual precipitation can trigger a significant increase in SSY, as was observed in the period May 2006 to May 2008. López-Tarazón and colleagues (2009) analyzed the same data and related the high sediment yield in these years to erosion by snowmelt, which may have caused a large sediment contribution that was retained in channels until floods occurred.

The relative contribution of the two sub-catchments was very similar for the 3 years of the calibration period (approximately 70\% for the Ésera River and 30\% for the Isábena River; Table 4). This was not surprising as the two catchments have similar geology and land cover characteristics, and the values reflect their relative sizes. 
3.2.2 Sediment yield in the long term, and a comparison with the depositional history of the Barasona Reservoir.

Table 5 shows the simulation results for sediment yield for the entire Barasona watershed over the period 1955-2008. The objective of the simulation was to predict the long-term averages of SY and SSY using an average value of the R-factor for that period. The average SY was estimated to be $0.56 \times 10^{6} \mathrm{Mg}_{\text {year }}{ }^{1}$ (Table 4). The sediment trapping coefficient for the Barasona Reservoir is $90.15 \%$ (Almorox et al., 1994), so the amount of sediment trapped in the reservoir was approximately $0.50 \times 10^{6} \mathrm{Mg}$ year $^{1}$. The SSY was estimated to be $3.73 \mathrm{Mg} \mathrm{ha}^{-1}$ year $^{1}$, a value very close to the long-term sediment yield of 3.50 Mg ha- ${ }^{-1}$ year ${ }^{1}$, obtained from a bathymetric survey. This result is significant as it validates the calibration performed using only 3 years of data from a single subcatchment in the area. However, this result must be taken with care, since three years of data are very few for a reliable estimation of the mean annual sediment yield in a complex basin.

This SSY yield obtained is similar to that estimated from reservoir sediment accumulation elsewhere in the Spanish Pyrenees. Almorox and associates (1994) obtained an estimate of $4.12 \mathrm{Mg} \mathrm{ha}^{-1}$ year $^{1}$ for the Yesa Reservoir in the Aragón River basin, and similar or higher numbers have been calculated for small experimental catchments in the French Alps (Mathys et al., 2005), the Eastern Pyrenees (Gallart et al., 2005), and the Central Pyrenees (García-Ruiz et al., 2008), which encompass a variety of bedrocks and climates. 
To assess the SDR (SY/gross erosion rate; expressed as a percentage) we calculated the gross soil erosion rate $\left(5.9 \times 10^{6} \mathrm{Mg}\right.$ year $\left.^{1}\right)$ as the net soil erosion for the area (i.e., total sediment production) before sediment was routed down the hillslopes to the stream network. The predicted SDR value at the outlet of the watershed was approximately $10 \%$, which is high but not extreme. For example, Van Rompaey and coworkers (2007) reported an SDR of $28 \%$ for a catchment of $1,960 \mathrm{~km}^{2}$ in the Czech Republic; Verstraeten and associates (2007) found SDR values of $20-39 \%$ for catchments of $164-2,173 \mathrm{~km}^{2}$ in Australia; Fryirs and Brierley (2001) estimated an extremely high SDR of almost $70 \%$ in the Bega River catchment (New South Wales, Australia), which caused dramatic changes to the river morphology; Romero Díaz and colleagues (1992) found SDR values of 7-46\% in the sub-catchments of the Segura River (Spain); and de Vente and co-workers (2008) predicted SDR values ranging from $0.03 \%$ to $55 \%$ for 61 catchments in Spain. In this latter study the SDR estimated for the watershed of the Barasona Reservoir was only $1.1 \%$, but the R-factor used was obtained from gridded mean monthly rainfall values, whereas the present study used precipitation data with a 15 min resolution. In addition, the K-factor used by de Vente and colleagues (2008) was based on erodibility maps from the European Soil Bureau, whereas we used a K-factor derived from soil samples collected at 76 sites within the area. These factors explain the order of magnitude difference in the estimates of total sediment production by de Vente's group (2008), relative to the values obtained in our analysis.

\subsubsection{Major sediment sources in the Barasona watershed}


The predicted sediment yield map for the period 1955-2008 was used to analyze the major sediment sources in the Barasona watershed (Fig. 8). The principal sediment sources were in the lowest part of the watershed, corresponding to fields under dryland crops, and the badlands on Eocene marls located in the middle part of the watershed (Pyrenean Inner Ranges; Fig. 8). In the upper part of the area (the Axial Pyrenees) the important erosion areas were mainly those at high elevation and with sparse land cover, but the transport of sediment from these areas to the stream network was only partial because of the presence of vegetation (Fig. 8B). The badland areas have high connectivity to the stream network, suggesting an elevated level of sediment supply (Fig. 8C). Moreover, the dryland crops were localized in a zone with low slope and relatively good connectivity (Fig. 8D).

Major differences in sediment yield were also found among land uses (Table 6). The principal sediment sources comprised four categories: the badland areas (CARCA), dryland crops (CUSEC), scrubland in sparse coniferous forest (MTBOP), and bare soil (SUDES); the SY values for these land uses types were moderate to high, ranging from 47,995 to $86,133 \mathrm{Mg}$ year ${ }^{1}$, and accounted for approximately $55 \%$ of the total SY in the watershed (Table 6).

The badland areas had the highest SSY (337 Mg ha- ${ }^{1}$ year $\left.^{1}\right)$. According to the Food and Agriculture Organization (FAO, 1980) this value is very high, and very similar to the $302 \mathrm{Mg} \mathrm{ha}^{-1}$ year $^{1}$ reported by Martínez-Casasnovas and Poch (1997) and the 600 Mg ha $^{1}$ year $^{1}$ reported by Regüés and colleagues (2000) for badlands in the Vallcebre catchment (eastern Pyrenees). Other studies have estimated erosion in the Spanish Pyrenees using remote sensing at regional (Beguería, 2006; Alatorre and Beguería, 2009) 
and catchment (Fargas et al., 1997) scales. These studies have shown that badland systems developed on Eocene marls constitute the main sediment sources in the Central Pyrenees, with important consequences for siltation of reservoirs (Valero-Garcés et al., 1999). In the Spanish Pyrenees a combination of favorable relief and climatic conditions is coupled with highly erodible marl outcrops, explaining the presence of badland systems with intense soil erosion processes (Regüés et al., 1995; Gallart et al., 2002; Nadal-Romero et al., 2007, 2008; Alatorre and Beguería, 2009).

Dryland crop areas had also high SSY $\left(80 \mathrm{Mg} \mathrm{ha}^{-1}\right.$ year $\left.^{1}\right)$ and accounted for an important fraction of the SY of the entire watershed because of the large area occupied by this land use. Scrubland in sparse coniferous forest had a moderate SSY of $42 \mathrm{Mg} \mathrm{ha}^{1}$ year $^{1}$, and bare soils (vegetal cover $15-50 \%$ ) had a SSY of $61 \mathrm{Mg} \mathrm{ha}^{-1}$ year ${ }^{1}$. The other land cover categories, which account for the largest fraction of the area, had lower SSY values ranging between: 2 and 29 (Table 6). In general, the values obtained were slightly higher than mean soil erosion rates reported for various land uses in Europe, as corresponds to a mountain area with high relief energy and long slope lengths. Thus, Kosmas and colleagues (1997) reported mean soil erosion rates of $0.008-1.43 \mathrm{Mg} \mathrm{ha}^{1}$ year $^{1}$ in plot studies under diverse land use/land cover conditions in France, Greece, Italy, Portugal, and Spain. Cerdán and associates (2006) reported mean rates of soil loss through sheet and rill erosion of $0.05-31.62 \mathrm{Mg} \mathrm{ha}^{-1}$ year $^{-1}$ for various land uses in Mediterranean environments, with an overall mean of $7.87 \mathrm{Mg} \mathrm{ha}^{-1}$ year ${ }^{1}$; however, the estimated average erosion rate was about $0.83 \mathrm{Mg} \mathrm{ha}^{-1} \mathrm{yr}^{1}$ if extreme erosion rates on bare soils and in vineyards were excluded. 
A total of 23 sub-catchments in the Barasona catchment were also analyzed, corresponding to the main rivers and tributaries (Fig. 9; for more details see Table 7). The sub-catchments in the Axial Pyrenees had the lowest SY values, with an average of 7,200 $\operatorname{Mg}$ year $^{1}\left(\sigma= \pm 6,800 \mathrm{Mg}\right.$ year $\left.^{1}\right)$. For sub-catchments in the Inner Depression, where the badlands on Eocene marls are located, the average SY was $30,900 \mathrm{Mg}^{\text {year }}{ }^{1}(\sigma= \pm$ 16,200 Mg year ${ }^{1}$ ), and sub-catchments in the prePyrenean sector had the highest SY values $\left(20,000-93,000 \mathrm{Mg}\right.$ year $^{1}$; average $=46,450 \mathrm{Mg}$ year $^{-1}, \sigma= \pm 29,000 \mathrm{Mg}$ year $\left.^{-1}\right)$; the largest extent of dryland crops was located in this sector.

There was a strong relationship between SY and catchment area, A, expressed as a logarithmic function (Fig. 10A). However, the catchment size was not the only variable explaining differences in sediment yield. The SSY, which relates the sediment yield (SY) to the catchment area (A), revealed a more complex pattern. In general the SSY is expected to decrease with increasing $\mathrm{A}$, as the travel time required for particles to reach the stream network increases, as does the number of sediment sinks available in the landscape (Parsons et al., 2006; de Vente et al, 2007). In our case a negative relationship between SSY and A was found for catchments in the Inner Depression and the prePyrenees, but an almost constant relationship was found for catchments in the Axial Pyrenees (Fig. 10B). The reasons for this may include the greater importance of channel erosion compared to hillslope erosion in the latter area, which is characterized by high mountain relief (de Vente et al., 2007). The Bacamorta sub-catchment (number 14) had the greatest SSY value $\left(14 \mathrm{Mg} \mathrm{ha}^{1}\right.$ year $\left.^{1}\right)$ and appeared as an outlier in the SSY/A plots, as a result of the relative importance of badlands in this catchment (15\%). The remaining 
sub-catchments had SSY values ranging from $1 \mathrm{Mg} \mathrm{ha}^{-1}$ year $^{1}$ (number 10, Urmella) to 7 $\mathrm{Mg} \mathrm{ha}^{-1}$ year $^{-1}$ (number 22, Pinares).

As sub-catchments are closed topographical units (except at the outlets), it was possible to compute the SDR for each sub-catchment. The SDR is a complex parameter that has been related to the area of the watershed, topographical conditions, relief energy, and rainfall (Gottschalk, 1964). A number of equations have been developed using area, runoff, relief, length, and bifurcation ratio as explanatory variables (Mitchell and Bubenzer, 1980; Wasson, 1994; Verstraeten et al., 2007). We found significant relationships between the SDR and A, expressed logarithmically (Fig. 10C and Table 8). With the exception of the equation for the Axial Pyrenees, the exponents of the exponential relationship were higher than those reported in previous studies, demonstrating the high variability of the SDR/A relationship and differences among geographical areas.

The results showed clear differences among structural geomorphologic units, both in the range of SDR values and in the slope of the SRD/A relationship. Sub-catchments in the Axial Pyrenees had the lowest SDR values (6-14\%), and the decrease in SDR with respect to catchment area was the smallest (exponent $=-0.1422$ ). Although this is a high mountain environment, there are many intermediate sediment storages in the form of small depressions, lakes, and perched flat areas, in addition to a land cover mosaic that favors sediment retention at the interface between patches; this configuration partly explains the low SDR values. However, the drainage density in the Axial Pyrenees is the highest in the study area $\left(1.11 \mathrm{~km} \mathrm{~km}^{-2}\right)$ and the sub-catchments have very steep slopes. 
This results in an overall good connectivity with the stream network, resulting in a relatively small decrease in the SDR within the catchment area.

The other two areas (the Inner Depression and the pre-Pyrenees) had higher average SDR values (7-22\%) and showed a much stronger relationship between SDR and $\mathrm{A}$ (exponents $=-0.7762$ and -0.6549 , respectively). The higher average values of the SDR in these two areas are attributable to erosive features that favor concentrated runoff processes such as badland formation, resulting in very high sediment delivery. In the prePyrenees sector the role of the badland areas as a sediment source is complemented by the predominance of dryland cultivation fields, which are responsible for delivering a large amount of sediment to the streams (Kosman et al., 1997; Molinillo et al., 1997; González-Hidalgo et al., 2007). However, apart from the badland areas, the overall drainage density is lower in these two sectors $\left(0.75\right.$ and $0.40 \mathrm{~km} \mathrm{~km}^{-2}$, respectively) than in the Axial Pyrenees, so the connectivity between sediment sources and the stream network decreases faster with increasing catchment areas.

\section{Conclusions}

In the present study sediment yield data derived from the depositional history of the Barasona Reservoir $\left(\mathrm{SSY}=3.50 \mathrm{Mg} \mathrm{ha}^{-1}\right.$ year $^{1}$ ) using 3 years (May 2005 to May 2008) of suspended sediment monitoring at the Capella station at the outlet of the Isábena River were used to calibrate the spatially distributed soil erosion and sediment delivery model, WATEM/SEDEM. It was concluded that a comparatively simple model with only elementary process descriptions can be used to predict regional scale annual sediment delivery from the hillslopes to the stream network with good accuracy. A consequence of 
the scale-dependence of model parameterization is that parameters have to be recalibrated if the model is to be run on another grid size or in other regions. In the present study WATEM/SEDEM was calibrated for a typical mountain watershed. Model predictions of SY and SSY were in good agreement with observed data. The NS and RRMSE statistics for SY were 0.97 and 0.08 , respectively. Calibration of the $k t c$ parameter for minimum (7) and maximum (23) transport capacity was in agreement with previous results reported to be optimal for watersheds of similar size and at the same spatial resolution, although under completely different environmental conditions (i.e. Verstraeten et al., 2007). The non-availability of spatially distributed data of soil erosion and sediment transport did not allow for a full two dimensional calibration, so a lumped approach was adopted by fixing the ratio between the two sediment transport parameters using literature values. This is a common compromise between users of WATEM/SEDEM, but it has the effect of introducing model uncertainty in the results concerning the spatial distribution of soil erosion and sedimentation.

Based on the model results, the long-term average sediment yield in the Barasona Reservoir watershed is $0.56 \times 10^{6} \mathrm{Mg}$ year $^{1}$ for a relative sediment yield of $3.73 \mathrm{Mg} \mathrm{ha}^{-1}$ year $^{1}$. A large proportion of the sediment comes from the lower part of the watershed (fields under dryland crops) and badlands on Eocene marls in the middle part of the watershed (the Inner Depression). The sediment budget showed that the Ésera subcatchment contributed approximately $70 \%$ of sediment yield to the reservoir. Estimates of the SDR indicated that only a small proportion $(10 \%)$ of total sediment production reached the catchment outlet over the period of the simulation (53 years). 
The use of a spatially continuous cascading model allowed detailed analysis of the relative contributions of different land uses and the sub-catchments of the basin. The relationships between gross sediment yield (SY; $\mathrm{Mg}_{\text {year }}{ }^{1}$ ), area-specific sediment yield (SSY; Mg ha ${ }^{1}$ year $^{1}$ ), and sediment delivery ratio (SDR), on the one hand, to the catchment area (A), on the other, differed among geomorphological units; this was attributable to differences in relief, drainage density, and land cover mosaic.

Spatially lumped models provide reasonable predictions of sediment yield but offer no insight into sediment sources. It is often claimed that the main advantages of spatially distributed approaches such as that of WATEM/SEDEM are that the model can serve as a decision-making tool for implementation of measures to prevent the on-site and off-site effects of soil erosion, and to asses the impacts of changes in land use or climate. However, the full potential of WATEM/SEDEM can only be reached if there is enough information to allow spatially distributed calibration of the sediment transport parameters. This requires data on soil erosion and deposition for different land uses within a catchment, and these data are very seldom available to the managers. As such, WATEM/SEDEM remains mainly as a researcher's tool, until either the problem of the scarcity of soil erosion data or the need for calibration of the transport parameters will be solved.

\section{Acknowledgments}

This research was financially supported by the projects CGL2006-11619/HID and CGL2008-00831/BTE, funded by CICYT, Spanish Ministry of Education and Science. 
The contribution of the first author was possible through a scholarship granted by The National Council for Science and Technology of Mexico (CONACYT). 


\section{References.}

Alatorre, L.C., Beguería, S., 2009. Identification of eroded areas using remote sensing in a badlands landscape on marls in the central Spanish Pyrenees. Catena 76, 182-190.

Almorox, J., De Antonio, R., Saa, A., Cruz Díaz, M., Gasco, J.M., 1994. Métodos de estimación de la erosión hídrica. Ed. Agrícola Española, 152 p.

Angulo-Martínez, M., López-Vicente, M., Vicente-Serrano, S.M., Beguería, S., 2009. Mapping rainfall erosivity at a regional scale: a comparison of interpolation methods in the Ebro Basin (NE Spain). Hydrology and Earth System Sciences Discussions 6, 417-453.

Angulo-Martínez, M., Beguería, S, 2009. Estimating rainfall erosivity from daily precipitation records: a comparison between methods in the Ebro Basin (NE Spain). Journal of Hydrology 379, 111-121.

Arnold, J.G., Srinivasan, R., Muttiah, R.S., Williams, J.R., 1998. Large area hydrologic modeling and assessment - Part 1: model development. Journal of the American Water Resources Association 34, 73-89.

Avendaño, C., Cobo, R., Sanz, M.E., Gómez, J.L., 1997a. Capacity situation in Spanish reservoirs. Proceedings of the Nineteenth Congress on Large Dams 74 (53), 849862.

Avendaño, C., Sanz, M.E., Cobo, R., Gómez, J.L., 1997b. Sediment yield at Spanish reservoirs and its relationships with the drainage basin area. Proceedings of the Nineteenth Congress on Large Dams 74 (54), 863-874.

Beguería, S., 2006. Identifying erosion areas at basin scale using remote sensing data and GIS. International Journal of Remote Sensing 20, 4585-4598. 
Box Jr., J.E., 1981. The effects of surface salty fragments on soil erosion by water. Soil Science Society of America Journal 45, 111-116.

Brown, L.C., Foster, G.R., 1987. Storm erosivity using idealized intensity distributions. Transactions of the ASAE 30, 379-386.

Cerdán, O., Poesen, J., Govers, G., Saby, N., LeBissonnais,Y., Gobin, A., Vacca, A., Quinton, J., Auerswald, K., Klik, A., Kwaad, F.P.M., Roxo, M.J., 2006. Sheet and rill erosion. In: Boardman, J., Poesen, J. (Eds.), Soil Erosion in Europe. John Wiley \& Sons, Ltd., pp. 501-513.

COST634, 2005. On- and Off-Site Environmental Impacts of Runoff and Erosion. European Cooperation in the Field of Scientific and Technical Research, http://www.soilerosion.net/cost634/.

Chueca, J., Julián, A., 2002. Rangos climáticos del macizo de la Madaleta (Pirineo Central Español). Boletin Glaciológico Aragonés 3, 113-130.

de Vente, J., Poesen, J., Arabkhedri, M. and Verstraeten, G., 2007. The sediment delivery problem revisited. Progress in Physical Geography, 31(2): 155-178.

de Vente, J., Poesen, J., Verstraeten, G., Van Rompaey, A., Govers, G., 2008. Spatially distributed modelling of soil erosion and sediment yield at regional scales in Spain. Global and Planetary Change 60, 393-415.

Del Barrio, G., Creus, J., Puigdefábregas, J., 1990. Thermal seasonality of the high mountain belts of the Pyrenees. Mountain Research and Development 10 (3), $227-$ 233. 
Desmet, P.J.J., Govers, G., 1996. A GIS procedure for automatically calculating the USLE LS factor on topographically complex landscape units. Journal of Soil and Water Conservation 51, 427-433.

DGA, 2006. Sistema de información territorial de Aragón. http://sitar.aragon.es/descargas/index.html

EC, 2002. Towards a Thematic Strategy for Soil Protection. Commission of the European Communities, Brussels.

FAO, 1980. Metodología provisional para la evaluación de la degradación de los suelos. UNESCO/PENUMA. Roma, Italia. 86 p.

Fargas, D., Martínez-Casasnovas, J.A., Poch, R.M., 1997. Identification of critical sediment source areas at regional level. Physics and Chemistry of the Earth 22, $355-359$.

Ferro, V., Minacapilli, M., 1995. Sediment delivery processes at basin scale. Hydrological Sciences Journal 40, 703-717.

Fryirs, K., Brierley, G.J., 2001. Variability in sediment delivery and storage along river courses in Bega catchment, NSW, Australia: implications for geomorphic river recovery. Geomorphology 38, 237-265.

Gallart, F., Llorens, P., Latron, J., Regües, D., 2002. Hydrological processes and their seasonal controls in a small Mediterranean mountain catchment in the Pyrenees. Hydrology and Earth System Sciences 6 (3), 527-537.

Gallart, F., Balasch, J.C., Regüés, D., Soler, M., Castelltort, F., 2005. Catchment dynamics in a Mediterranean mountain environment: the Vallcebre research basins (southeastern Pyrenees) II: temporal and spatial dynamics of erosion and stream 
sediment transport. In: García, C., Batalla, R.J. (Eds.), Catchment dynamics and river processes: Mediterranean and other climate regions. Developments in Earth Surface Processes 7, 17-29.

García-Ruiz, J.M., Beguería, S., López Moreno, J.I., Lorente, A., Seeger, M., 2001. Los recursos hídricos superficiales del Pirineo aragonés y su evolución reciente. Geoforma, Logroño, 192 pp.

García-Ruiz, J.M., Regües, D., Olvera, B., Lana-Renault, N., Serrano-Muela, P., Nadal_Romero, E., Navas, A., Latron, J., Martí-Bono, C., Arnáes, J., 2008. Flood generation and sediment transport in experimental catchments along a plant cover gradient in the Central Pyrenees. Journal of Hydrology 356, 245-260.

González-Hidalgo, J.C., Peña-Monné, J.L., De Luis, M., 2007. A review of dialy soil erosion in Western Mediterranean areas. Catena 71, 193-199.

Gottschalk, L.C., 1964. Chap. 17 in Chow, V.T. ed. 1, Handbook of Applied Hydrology. MacGraw Hill. New York.

Jäger, S., 1994. Modelling regional soil erosion susceptibility using the USLE and GIS. In: Rickson, R.J. (Ed.), Conserving Soil Resources: European Perspectives. CAB International, Wallingford, UK, pp. 161-177.

Keesstra, S.D., van Dam, O., Verstraeten, G., van Huissteden, J., 2009. Changing sediment dynamics due to natural reforestation in the Dragonja catchment, SW Slovenia. Catena 78 (1), 60-71.

Kosmas, C., Danalatos, N., Cammeraat, L.H., Chabart, M., Diamantopoulos, J., Farand, R., Gutierrez, L., Jacob, A., Marques, H., Martinez-Fernandez, J., 1997. The effect 
of land use on runoff and soil erosion rates under Mediterranean conditions. Catena $29(1), 45-59$.

López-Moreno, J.I., Beguería, S., García-Ruiz, J.M., 2002. El régimen del río Ésera, Pirineo Aragonés, y su tendencia reciente. Boletín Glaciológico Aragonés 3, 131162.

López-Moreno, J.I., García-Ruiz, J.M., (2004). Influence of snow accumulation and snowmelt on streamflow in the Central Spanish Pyrenees. International Journal of Hydrological Sciences 49 (5), 787-802.

López-Tarazón, J.A., Batalla, R.J., Vericat, D., Francke T., 2009. Suspended sediment transport in a highly erodible catchment: the river Isábena (Central Pyrenees). Geomorphology, doi: 10.1016/j.geomorph.2009.03.003.

Lu, H., Gallant, J., Prosser, I.P., Moran, C., Priestly, G., 2001. Prediction of sheet and rill erosion of the Australian continent: incorporating monthly soil loss distribution. Technical Report 13/01, CSIRO Land and Water, Canberra. http://www.clw.csiro.au/publications/technical2001/tr13-01.pdf.

Machín, J., 1990. Mapa de suelos de Áragon (Soil map of Aragón) 1:100,000. Unpublished document, Estación Experimental de Aula Dei, Zaragoza.

Martínez-Casasnovas, J.A., Poch, R.M., 1997. Estado de conservacion de los suelos de la cuenca del embalse 'Joaquín Costa'. Proceedings of 'Encuentrocientífico-técnico sobre el vaciado total y prolongado del embalse de Joaquin Costa'. Ministerio de Medio Ambiente—Confederación Hidrográfica del Ebro. Zaragoza. 
Mathys, N., Klotz, S., Esteves, M., Descroix, L., Lapetite, J.M., 2005. Runoff and erosion in the Black Marls of the French Alps: Observations and measurements at the plot scale. Catena 63, 261-281.

Mitchell, J.K., Bubenzer, G.D., 1980. Soil loss estimation. In: KIRKBY, M.J.; MORGAN, R.P.C. (Ed.). Soil erosion. Chichester: John Wiley \& Sons, p.17-62.

Molinillo, M., Lasanta, T., García-Ruiz, J.M., 1997. Managing mountainous degraded landscapes after farmland abandonment in the Central Spanish Pyrenees. Environmental Management 21, 587-598.

Nadal-Romero, E., Regüés, D., Martí-Bono, C., Serrano-Muela, P., 2007. Badlands dynamics in the Central Pyrenees: temporal and spatial patterns of weathering processes. Earth Surfaces Processes and Landforms 32 (6), 888-904.

Nadal-Romero, E., Latron, J., Martí-Bono, C., Regüés, D., 2008. Temporal distribution of suspended sediment transport in a humid Mediterranean badland area: the Araguás catchment, Central Pyrenees. Geomorphology 97, 601-616.

Nash, J.E., Sutcliffe, J.V., 1970. River flow forecasting through conceptual models: Part 1: a discussion of principles. Journal of Hydrology 10, 282-290.

Navas, A., Valero, B., Machín, J., Walling, D., 1998. Los sedimentos del embalse Joaquín Costa y la historia de su depósito. Limnética 14, 93-112.

Osterkamp, W.R., Toy, T.J., 1997. Geomorphic considerations for erosion prediction. Environmental Geology 29, 152-157.

Parsons, A.J., Wainwright, J., Brazier, R.E. and Powell, D.M., 2006b. Is sediment delivery a fallacy? Earth Surface Processes and Landforms 31(10), 1325-1328. 
Planchon, O. Darboux, F., 2001. A fast, simple and versatile algorithm to fill the depressions of digital elevation models. Catena 46, 159-176.

Prosser, I.P., Rustomji, P., Young, B., Moran, C., Hughes, A., 2001. Constructing river basin sediment budgets for the National Land and Water Resources Audit. CSIRO Land and Water Technical Report 15/01, Canberra, Australia, http://www.clw.csiro.au/publications/technical2001/tr15-01.pdf.

Regüés, D., Pardini, G., Gallart, F., 1995. Regolith behaviour and physical weathering of clayey mudrock as dependent on seasonal weather conditions in a badland area at Vallcebre, Eastern Pyrenees. Catena 25 (1-4), 199-212.

Regüés D., Balasch J., Castelltort X., Soler M., Gallart F., 2000. Relación entre las tendencias temporales de producción y transporte de sedimentos y las condiciones climáticas en una pequeña cuenca de montaña mediterránea (Vallcebre, Eastern Pyrenees). Cuadernos de Investigación Geográfica 26, 24-41.

Renard, K.G., Foster, G.R., Weesies, G.A., Porter, J.P., 1991. RUSLE-revised universal soil loss equation. Journal of Soil and Water Conservation 46, 30-33.

Renfro, G.W. 1975. Use of erosion equations and sediment delivery ratios for predicting sediment yield. In: Present and Prospective Technology for Predicting Sediment Yield and Sources. Publication ARS-S-40. US Department of Agriculture: Washington, DC. p. 3345.

Roehl, J.E., 1962. Sediment source areas, delivery ratios and influencing morphological factors. IAHSPubl. No.59, p.202-213.

Romero Díaz, M.A., Cabezas, F., López Bermúdez, F., 1992. Erosion and fluvial sedimentation in the River Segura Basin (Spain). Catena 19, 379-392. 
Römkens, M., Prasad, J., Poesen, J., 1987. Soil erodibility and properties. Transactions of the XIII Congress of International Society of Soil Science vol. V, p. 492- 504.

Sanz-Montero, M., Cobo-Rayán, R., Avendaño-Salas, C., Gómez-Montaña, J., 1996. Influence of the drainage basin area on the sediment yield to Spanish reservoirs. In: Proceedings of the First European Conference and Trace Exposition on Control Erosion.

Schröter, D., Cramer, W., Leemans, R., Prentice, I.C., Araujo, M.B., Arnell, N.W., Bondeau, A., Bugmann, H., Carter, T.R., Gracia, C.A., de la Vega-Leinert, A.C., Erhard, M., Ewert, F., Glendining, M., House, J.I., Kankaanpaa, S., Klein, R.J.T., Lavorel, S., Lindner, M., Metzger, M.J., Meyer, J., Mitchell, T.D., Reginster, I., Rounsevell, M., Sabate, S., Sitch, S., Smith, B., Smith, J., Smith, P., Sykes,M.T., Thonicke, K., Thuiller, W., Tuck, G., Zaehle, S., Zierl, B., 2005. Ecosystem service supply and vulnerability to global change in Europe. Science 310 (5752), 13331337.

Takken, I., Beuselinck, L., Nachtergaele, J., Govers, G., Poesen, J., Degraer, G., 1999. Spatial evaluation of a physically-based distributed erosion model (LISEM). Catena $37(3-4), 431-447$.

Takken, I., Govers, G., Jetten, V., Nachtergaele, J., Steegen, A., Poesen, J., 2005. The influence of both process descriptions and runoff patterns on predictions from a spatially distributed soil erosion model. Earth Surface Processes and Landforms 30 (2), 213-229.

UN, 1994. United Nations Convention to Combat Desertification in those Countries Experiencing Serious Drought and/or Desertification, Particularly in Africa, Paris. 
USDA, 1972. Sediment sources, yields, and delivery ratios. National Engineering Handbook, Section 3 Sedimentation.

Valero-Garcés, B.L., Navas, A., Machín, J., Walling, D., 1999. Sediment sources and siltation in mountain reservoirs: a case study from the Central Spanish Pyrenees. Geomorphology 28, 23-41.

Van der Knijff, J.M., Jones, R.J.A., Montanarella, L., 2000. Soil erosion risk assessment in Europe. European Soil Bureau, Joint Research Centre, EUR 19044 EN, 34 p.

Van Oost, K., Govers, G., Desmet, P.J.J., 2000. Evaluating the effects of landscape structure on soil erosion by water and tillage. Landscape Ecology 15 (6), 579-591.

Van Rompaey, A., Govers, G., Waumans, T., Van Oost, K., Poesen, J., Desmet, J., 2000. A regional soil erosion risk map for Flanders (Belgium), @WEL 3 (2000), 1-6 pp.

Van Rompaey, A.J.J., Verstraeten, G., Van Oost, K., Govers, G., Poesen, J., 2001 a. Modelling mean annual sediment yield using a distributed approach. Earth Surface Processes and Landforms 26, 1221- 1236.

Van Rompaey, A., Verstraeten, G., Van Oost, K., Rozanov, A., Govers, G., Poesen, J., 2001b. Modelling sediment transport in the Jonkershoek catchment. Part 1: Model calibration and validation. In: Cartographic modelling of land degradation, Proceedings of the Workshop held in Ghent (September 2001) in the framework of the Bilateral Cooperation between Flanders and South-Africa: 75-89.

Van Rompaey, A., Krasa, J., Dostal, T., Govers, G., 2003a. Modelling sediment supply to rivers and reservoirs in Eastern Europe during and after the collectivization period. Hydrobiologia 494, 169-176. 
Van Rompaey, A., Verstraeten, G., Van Oost, K., Rozanov, A., Govers, G. and Poesen, J., 2003b. Modelling sediment fluxes in the Jonkershoek catchment. Part 1: model calibration and validation. Proceedings of the workshop Cartographic modeling of and degradation. Ghent, Belgium, p. 75-89.

Van Rompaey, A., Bazzoffi, P., Jones, R.J.A., Montanarella, L., 2005. Modelling sediment yields in Italian catchments. Geomorphology 65, 157-169.

Van Rompaey, A., Krasa, J., Dostal, T., 2007. Modelling the impact of land cover changes in the Czech Republic on sediment delivery. Land Use Policy 24, 576-583.

Vanoni, V.A., 1975. Sedimentation engineering. ASCE Manuals and Reports on Engineering Practices 54.

Verstraeten, G., 2006. Regional scale modelling of hillslope sediment delivery with SRTM elevation data. Geomorphology 81, 128-140.

Verstraeten, G., Poesen, J., 2001. Factors controlling sediment yield from small intensively cultivated catchments in a temperate humid climate. Geomorphology $40,123-144$.

Verstraeten, G., Poesen, J., 2002. Using sediment deposits in small ponds to quantify sediment yield from small catchments: possibilities and limitations. Earth Surface Processes and Landforms 27, 1425-1439.

Verstraeten, G., Prosser, I.P., 2008. Modelling the impact of land-use change and farm dam construction on hillslope sediment delivery to rivers at the regional scale. Geomorphology 98, 199-212.

Verstraeten, G., Van Rompaey, A., Van Oost, K., Rozanov, A., Poesen, J., Govers, G., 2001. Modelling sediment transport in the Jonkershoek catchment. Part 2: 
Evaluating the impact of possible land use changes on sediment delivery to the Eerste Rivier and the Jonkershoek reservoir. In: Cartographic modelling of land degradation, Proceedings of the Workshop held in Ghent (September 2001) in the framework of the Bilateral Cooperation between Flanders and South-Africa: 91-99.

Verstraeten, G., Van Oost, K., Van Rompaey, A., Poesen, J., Govers, G., 2002. Evaluating an integrated approach to catchment management to reduce soil loss and sediment pollution through modelling. Soil Use and Management 18, 386-394.

Verstraeten, G., Poesen, J., Gillijns, K., Govers, G., 2006. The use of riparian vegetated filter strips to reduce river sediment loads: an over-estimated control measure? Hydrological Processes 20, 4259-4267.

Verstraeten, G., Prosser, I.P., Fogarty, P., 2007. Predicting the spatial patterns of hillslope sediment delivery to river channels in the Murrumbidgee catchment,Australia. Journal of Hydrology 334 (3-4), 440-454.

Vigiak, O., Sterk, G., Romanowicz, R.J., Beven, K.J., 2006. A semi-empirical model to assess uncertainty of spatial patterns of erosion. CATENA 66 (3), 198-210.

Walling, D.E., 1983. The sediment delivery problem. Journal of Hydrology 65, 209-237.

Wasson, R.J., 1994. Annual and decadal variation in sediment yield in Australia, and some global comparisons. In: Variability in stream erosion and sediment transport (Proceedings of the Canberra Symposium, December 1994). IAHS Publication 224, 269-279.

Williams, J.R., 1975. Sediment routing from agricultural watersheds. Water Resources Bulletin 11, 965-974. 
Wischmeier, W.H., Smith, D.D., 1978. Predicting rainfall-erosion losses: A guide to conservation planning. Agriculture Handbook \#507. USDA, Washington, DC. 


\section{Figure captions}

Figure 1. Location of the Barasona watershed study area and rain gauge stations (P029 Samper, P030 Las Paules, P031 Casallera, P032 Castigaleu, E046 Mediano, E047 E1 Grado, E050 Escales, E065 Baserca, A258 Ésera-Campo, A047 Isábena-Capella, C081 E1 ciego); Capella flow gauge station (A047). The photograph shows silting of the Barasona Reservoir.

Figure 2. Description of the study area: A) digital terrain model (DTM); B) lithologic map (DGA, 2006) and structural geomorphologic units of the Ésera-Isábena watershed; C) soil types (Machin, 1990); and D) land use map derived from CORINE (2000) land cover data.

Figure 3. Comparison of the drainage network map from the Ebro River Water Authority $(\mathrm{CHE})$ at the 1:50,000 scale (dashed lines) and the drainage network derived from the DTM using a threshold value of $1 \mathrm{~km}^{2}$ contributing area (continuous line). The area shown is $12 \times 12 \mathrm{~km}$.

Figure 4. Input data derived from the database of the Ésera-Isábena watershed: A) parcel map, derived from the land use/land cover map; B) soil erodibility map (K-factor in RUSLE, Mg h MJ- ${ }^{1} \mathrm{~mm}^{-1}$ ); C) rainfall erosivity map (R-factor in RUSLE, MJ mm ha- ${ }^{1} \mathrm{~h}^{1}$ $\left.\mathrm{yr}^{-1}\right)$; and D) crop management map (C-factor in RUSLE). 
Figure 5. Calibration of the transport capacity parameters $k t c_{\min }$ and $k t c_{\max }(\mathrm{m})$ in the Isábena sub-catchment based on annual sediment yield (SY) data at the Capella gauge station, outlet of the Isábena River (López-Tarason et al., 2009): goodness of fit surface plots as measured by the RRMSE (left) and the NS (right) statistics on the two dimensional space determined by both parameters. In both cases green represents the best fit. The slashed line on both plots represents a 1/3 relationship between $k t c_{\text {min }}$ and $k t c_{\max }$.

Figure 6. Calibration of the transport capacity parameters $k t c_{\min }$ and $k t c_{\max }(\mathrm{m})$ in the Isábena sub-catchment based on annual sediment yield (SY) data at the Capella gauge station, outlet of the Isábena River (López-Tarason et al., 2009), when the ratio between them was kept constant (1:3.33): RRMSE (left) and NS (right) statistics.

Figure 7. Comparison of precipitation and runoff over the period 1955 to 2008 (CHE).

Figure 8. Map of predicted sediment delivery from hillslopes to the stream network in the Ésera-Isábena watershed, and the principal sediment sources: A) predicted SY and SSY for the entire study area; B) Axial Pyrenees; C) Inner Depression (badlands on Eocene marls); and D) prePyrenean sector (dryland crops).

Figure 9. Sediment sources in the Ésera-Isábena watershed by sub-catchment (see Table 7 for a list of sub-catchments). 
Figure 10. Changes in the sediment delivery ratio throughout the Ésera-Isábena watershed: sub-catchments in the Axial Pyrenees (triangles), the Inner Depression (squares) and the prePyrenean sector (circles). 
Table 1. Average annual sediment delivery data for the Ésera and Isábena basins.

\begin{tabular}{lccccc}
\hline Drainage basin & $\begin{array}{c}\text { Size } \\
\left(\mathrm{km}^{2}\right)\end{array}$ & $\begin{array}{c}\text { Observed } \\
\text { period (y) }\end{array}$ & $\begin{array}{c}\text { Obs. } \\
\text { Method }\end{array}$ & SY (Mg yr $\left.{ }^{-1}\right)$ & SSY (Mg ha $\left.{ }^{-1} \mathrm{yr}^{-1}\right)$ \\
\hline Ésera-Isábena (1932-1996) & 1504 & 64 & WD & 526,400 & 3.50 \\
Isábena (May 2005 to May 2006) & 438 & 1 & GS & 90,410 & 2.03 \\
Isábena ((May 2006 to May 2007) & 438 & 1 & GS & 250,290 & 5.62 \\
Isábena ((May 2007 to May 2008) & 438 & 1 & GS & 212,070 & 4.77 \\
\hline
\end{tabular}

*Observation method: WD = measurement of water depths in the Barasona Reservoir in 1996 (Sanz Montero et al., 1996); GS = measurement at the gauge station in the Isábena River (López-Tarazón et al., 2009). SY: sediment yield $\left(\mathrm{Mg} \mathrm{yr}^{-1}\right)$; SSY: average annual area-specific sediment yield $\left(\mathrm{Mg} \mathrm{ha}^{-1} \mathrm{yr}^{-1}\right)$. 
Table 2. Values of the C-factor assigned to the Corine land cover/land use map.

\begin{tabular}{|c|c|c|c|c|c|}
\hline Land use & Category & $\begin{array}{l}\text { C factor } \\
\text { value }\end{array}$ & Land use & Category & $\begin{array}{l}\text { C factor } \\
\text { value }\end{array}$ \\
\hline Grassland with sparse bare soil & AGRNS & 0.250 & Opencast mine & MINAS & 0.800 \\
\hline Mixed conifers and deciduous forest & BMIXT & 0.012 & $\begin{array}{l}\text { Scrubland in sparse coniferous } \\
\text { forest }\end{array}$ & MTBOP & 0.080 \\
\hline Badlands & CARCA & 0.800 & Alpine grassland & MTHU & 0.200 \\
\hline Spaces in construction & CONST & 0.000 & Dense scrubland & MTMT & 0.080 \\
\hline Herbaceous agriculture & CUREH & 0.040 & Scrubland with low density & MTPD & 0.200 \\
\hline Dryland crops & CUSEC & 0.250 & Olive tree orchards & OLIVOS & 0.400 \\
\hline Sport installations & DEPOR & 0.000 & Areas with sparse vegetation & OROF & 0.700 \\
\hline Reservoirs & EMBAL & 0.000 & Grassland & PASTIM & 0.120 \\
\hline Evergreen forest & ENCIQ & 0.045 & Conifers & PINOS & 0.012 \\
\hline Deciduous forest & FRCA & 0.034 & Grassland & PRADE & 0.004 \\
\hline Vineyard in dryland & FRUS & 0.400 & Grassland of wet clime & PSSUH & 0.150 \\
\hline Glacier & GLACI & 0.800 & Ephemeral watercourse & RAMBLA & 0.800 \\
\hline Industry zone & INDUSI & 0.000 & Rivers banks & RIBERA & 0.034 \\
\hline Lake & LAGO & 0.000 & Bare rock & ROCPT & 0.800 \\
\hline $\begin{array}{l}\text { Mosaic of annual crops with permanent crops } \\
\text { in dryland } \\
\text { Mosaic of annual crops with permanent }\end{array}$ & MCAPES & 0.250 & Bare soil & SUDES & 0.800 \\
\hline pasture in dryland & MCAPRS & 0.250 & Peat bog & TURBA & 0.800 \\
\hline Mosaic of permanent irrigated crops & MCPR & 0.040 & Urban zone-continuous & URBC & 0.000 \\
\hline Mosaic of permanent dryland crops & MCPS & 0.250 & Urban zone-discontinuous & URBDE & 0.000 \\
\hline Mixed deciduous forest & MFROND & 0.010 & Open urban infrastructure & URBDL & 0.000 \\
\hline
\end{tabular}


Table 3. Predicted sediment yield (SY) and specific sediment yield (SSY) from the hillslopes to the river network in the Isábena sub-catchment, based on the best parameterization of $k t c_{\max }$ and $k t c_{\min }$ from calibration (23 and $7 \mathrm{~m}$, respectively).

\begin{tabular}{lrrrrr}
\hline Period & $\begin{array}{r}\text { R-factor } \\
\left(\mathrm{MJ} \mathrm{mm} \mathrm{ha}^{-1} \mathrm{~h}^{-1}\right)\end{array}$ & $\begin{array}{r}\text { SY modeled } \\
\left(\mathrm{Mg} \mathrm{yr}^{-1}\right)\end{array}$ & $\begin{array}{r}\text { SY observed } \\
\left(\mathrm{Mg} \mathrm{yr}^{-1}\right)\end{array}$ & $\begin{array}{r}\text { SSY modeled } \\
\left(\mathrm{Mg} \mathrm{ha}^{-1} \mathrm{yr}^{-1}\right)\end{array}$ & $\begin{array}{r}\text { SSY observed } \\
\left(\mathrm{Mg} \mathrm{ha}^{-1} \mathrm{yr}^{-1}\right)\end{array}$ \\
\hline May 2005 to May 2006 & 937 & 108,178 & 90,410 & 2.47 & 2.03 \\
May 2006 to May 2007 & 2180 & 250,686 & 250,290 & 5.72 & 5.62 \\
May 2007 to May 2008 & 1900 & 219,360 & 212,070 & 5.01 & 4.77 \\
\hline
\end{tabular}


Table 4. Predicted sediment yield (SY) and specific sediment yield (SSY) from the hillslopes to the river network for the entire Barasona watershed (Isábena and Ésera rivers) in the three years used for calibration, based on the best parameterization of $k t c_{\max }$ and $k t c_{\min }$ (23 and $7 \mathrm{~m}$, respectively), and the percent contribution from the Ésera catchment.

\begin{tabular}{lrrr}
\hline Period & SY $\left(\mathrm{Mg} \mathrm{yr}^{-1}\right)$ & SSY $\left(\mathrm{Mg} \mathrm{ha}^{-1} \mathrm{yr}^{-1}\right)$ & $\begin{array}{r}\text { Contribution } \\
\text { Ésera river (\%) }\end{array}$ \\
\hline May 2005 to May 2006 & 404,495 & 2.69 & 68 \\
May 2006 to May 2007 & 941,087 & 6.26 & 71 \\
May 2007 to May 2008 & 820,214 & 5.45 & 71 \\
\hline
\end{tabular}


Table 5. Long-term predicted gross erosion, sediment yield (SY), specific sediment yield (SSY) and sediment delivery ratio (SDR) for the entire Barasona watershed, based on the best parameterization of $k t c_{\max }$ and $k t c_{\min }(23$ and $7 \mathrm{~m}$, respectively), and the percent contribution from the Ésera catchment.

\begin{tabular}{lrrrrrr}
\hline Period & $\begin{array}{r}\text { R-factor } \\
\left(\mathrm{MJ} \mathrm{mm} \mathrm{ha}^{-1} \mathrm{~h}^{-1}\right)\end{array}$ & $\begin{array}{r}\text { Gross erosion } \\
\left(\mathrm{Mg} \mathrm{yr}^{-1}\right)\end{array}$ & $\begin{array}{r}\text { SY } \\
\left(\mathrm{Mg} \mathrm{yr}^{-1}\right)\end{array}$ & $\begin{array}{r}\text { SSY } \\
\left(\mathrm{Mg} \mathrm{ha}^{-1} \mathrm{yr}^{-1}\right)\end{array}$ & $\begin{array}{r}\text { Contribution } \\
\text { Esera river (\%) }\end{array}$ & $\begin{array}{r}\text { SDR } \\
(\%)\end{array}$ \\
\hline $1955-2008$ & 1323 & $5,907,963$ & 561,199 & 3.73 & 70 & 10.52 \\
\hline
\end{tabular}


Table 6. Predicted sediment yield (SY) and specific sediment yield (SSY) for each land uses/land cover type (CLC, 2000).

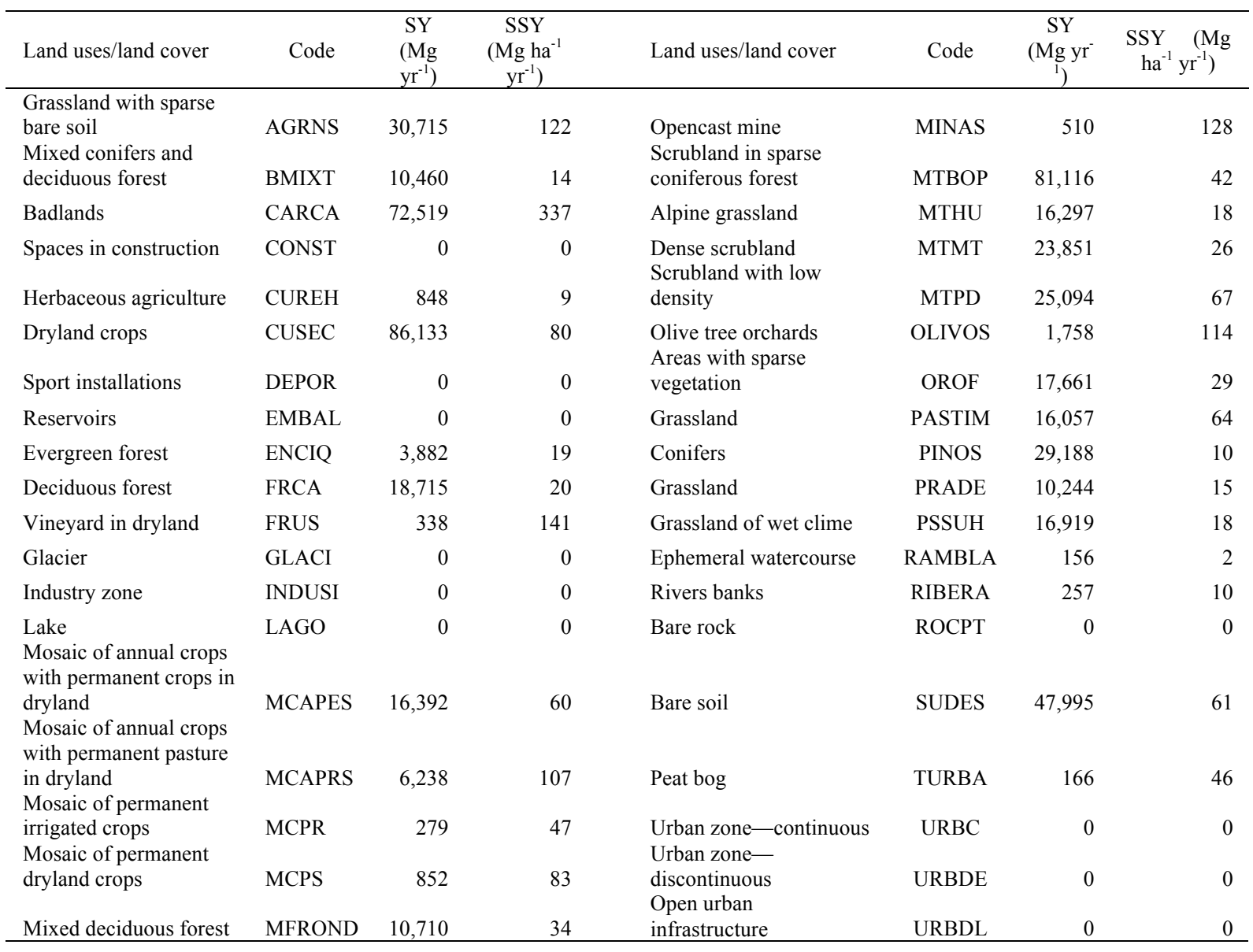


Table 7. Sub-catchments of the Ésera-Isábena watershed: Axial Pyrenees (codes 1-10);

Inner Depression (codes 11-18); and pre-Pyrenees sector (codes 19-23).

\begin{tabular}{|c|c|c|c|c|c|}
\hline Code & Catchments & Area (ha) & Code & Catchments & Area (ha) \\
\hline 1 & Llisat basin & 219,408 & 13 & Ésera River basin (intermediate sector) & $1,638,270$ \\
\hline 2 & Ibones de Eriste basin & 15,468 & 14 & Bacamorta basin & 312,768 \\
\hline 3 & Eriste River basin & 371,156 & 15 & Rialbo River basin & 747,392 \\
\hline 4 & Ibones de Eriste basin & 21,304 & 16 & Gabás basin & 274,980 \\
\hline 5 & Ibones de Batisielles/Perramó basin & 53,328 & 17 & Villacarlí basin & 426,608 \\
\hline 6 & Estós River basin & 445,696 & 18 & Isábena River basin (headwater) & $1,601,940$ \\
\hline 7 & Ésera River basin (headwater) & 807,296 & 19 & Isábena River basin (low sector) & $1,882,660$ \\
\hline 8 & Vallibierna basin & 351,164 & 20 & Ribera basin & 473,236 \\
\hline 9 & Peñascaro basin & 323,748 & 21 & San Marcial basin & $1,153,000$ \\
\hline 10 & Urmella basin & 287,516 & 22 & Pinares basin & 455,748 \\
\hline 11 & Viu basin & 356,748 & 23 & Ésera River basin (low sector) & $2,240,580$ \\
\hline 12 & Barbaruéns basin & 584,996 & & & \\
\hline
\end{tabular}


Table 8. Relationships between the sediment delivery ratio (SDR) and the catchment area for the Barasona Reservoir catchment in this study (Axial Pyrenees, Inner Depression and pre-Pyrenees;), and from other published reports.

\begin{tabular}{llll}
\hline Relationship & $\mathrm{R}^{2}$ & Study area & Reference \\
\hline$S D R=13.329 A^{-0.1422}$ & 0.53 & Axial Pyrenees & \\
$S D R=139.97 A^{-0.7762}$ & 0.81 & Inner Depression & \\
$S D R=252.29 A^{-0.6549}$ & 0.72 & pre-Pyrenees & \\
$S D R=0.42 A^{-0.125}$ & & & Vanoni (1975) \\
$S D R=0.51 A^{-0.110}$ & & & USDA (1972) \\
$S D R=1.7935 A^{-0.1419}$ & & & Renfro (1975) \\
\hline
\end{tabular}


Figure 1
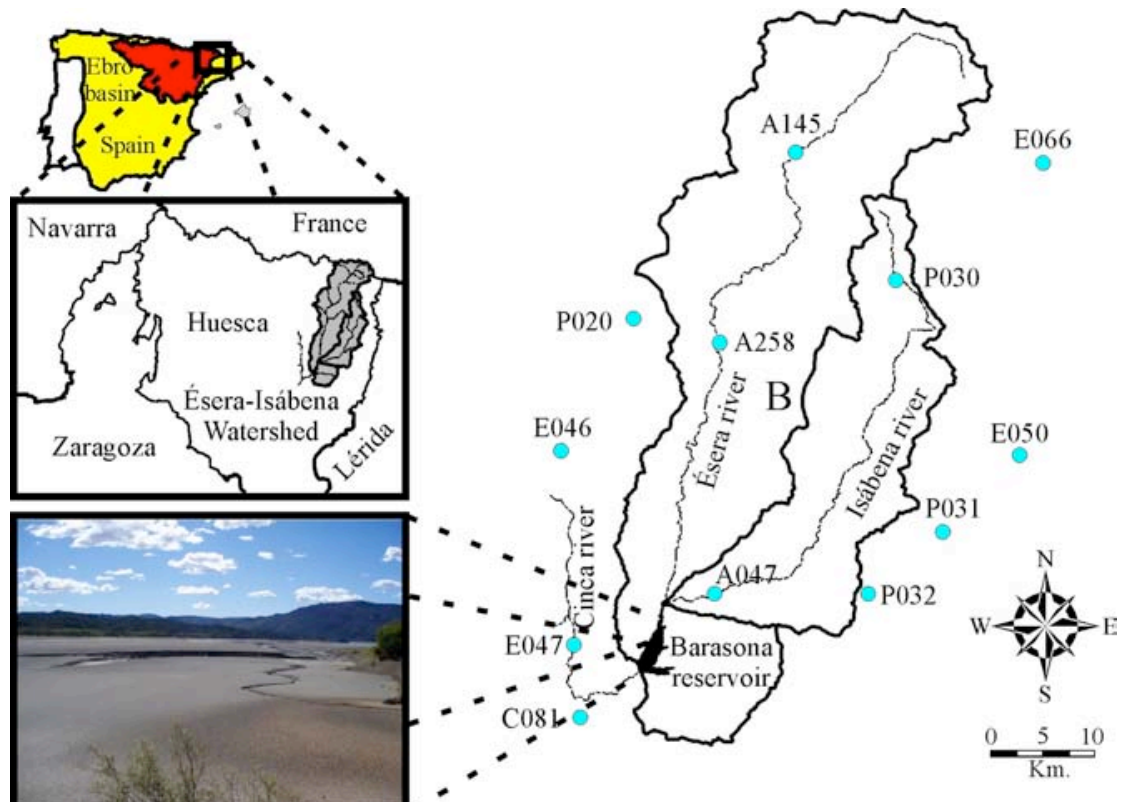
Figure 2

A) Digital Terrain Model

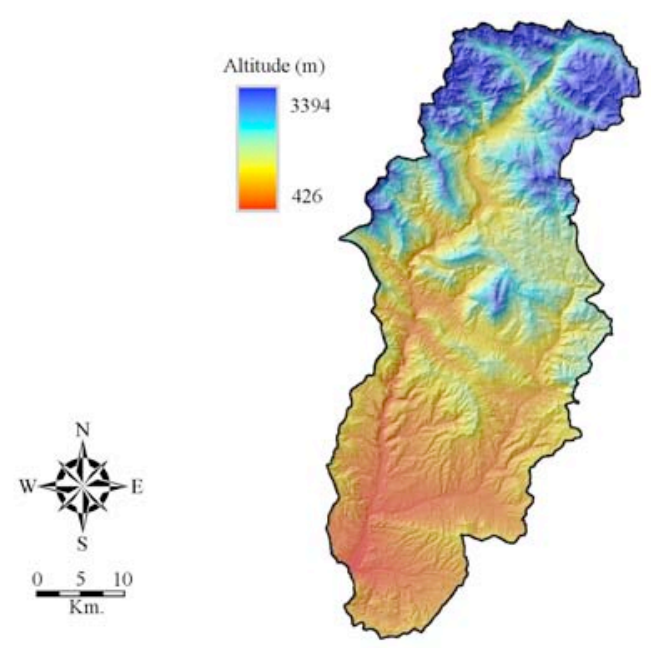

C) Soil types

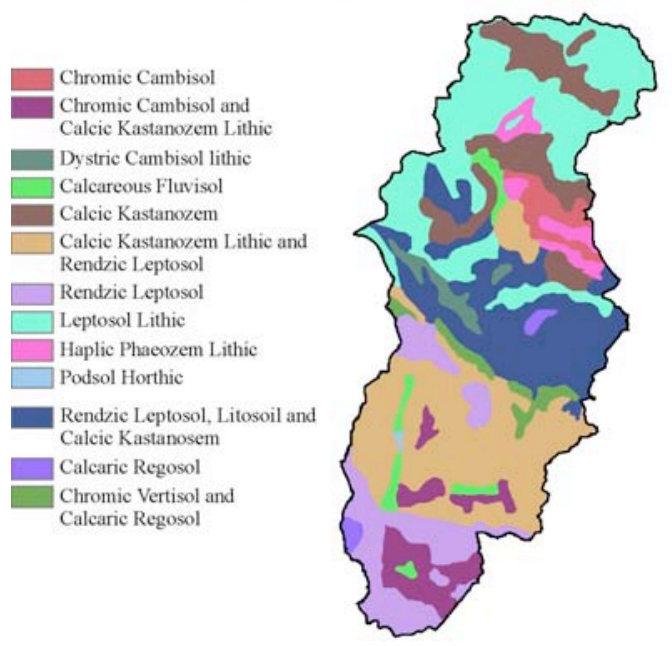

\section{B) Lithology}

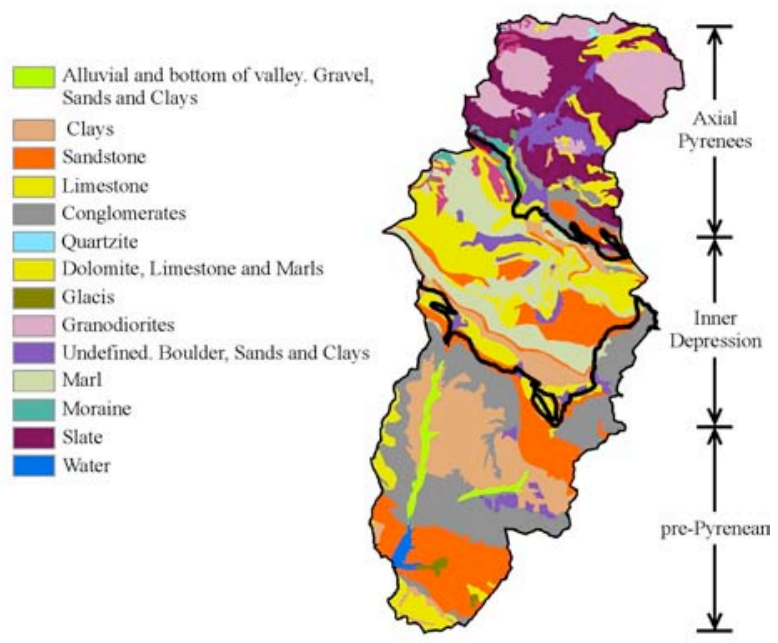

D) Land Use/land cover

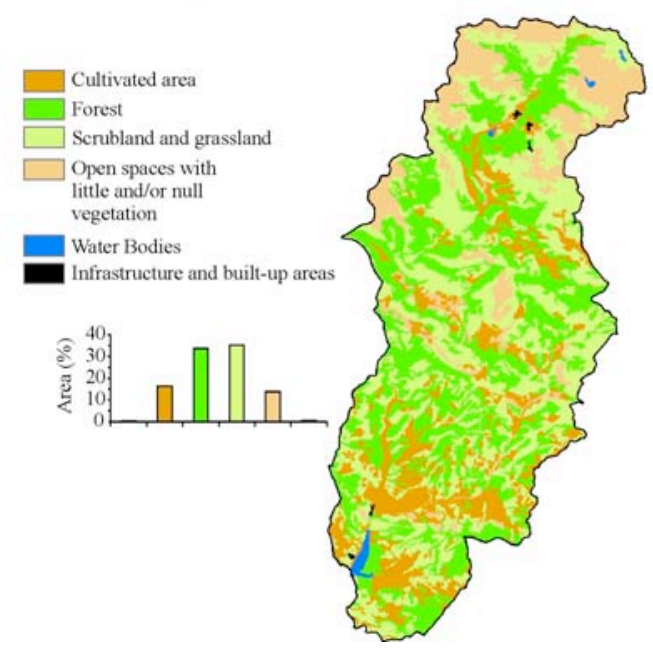


Figure 3.

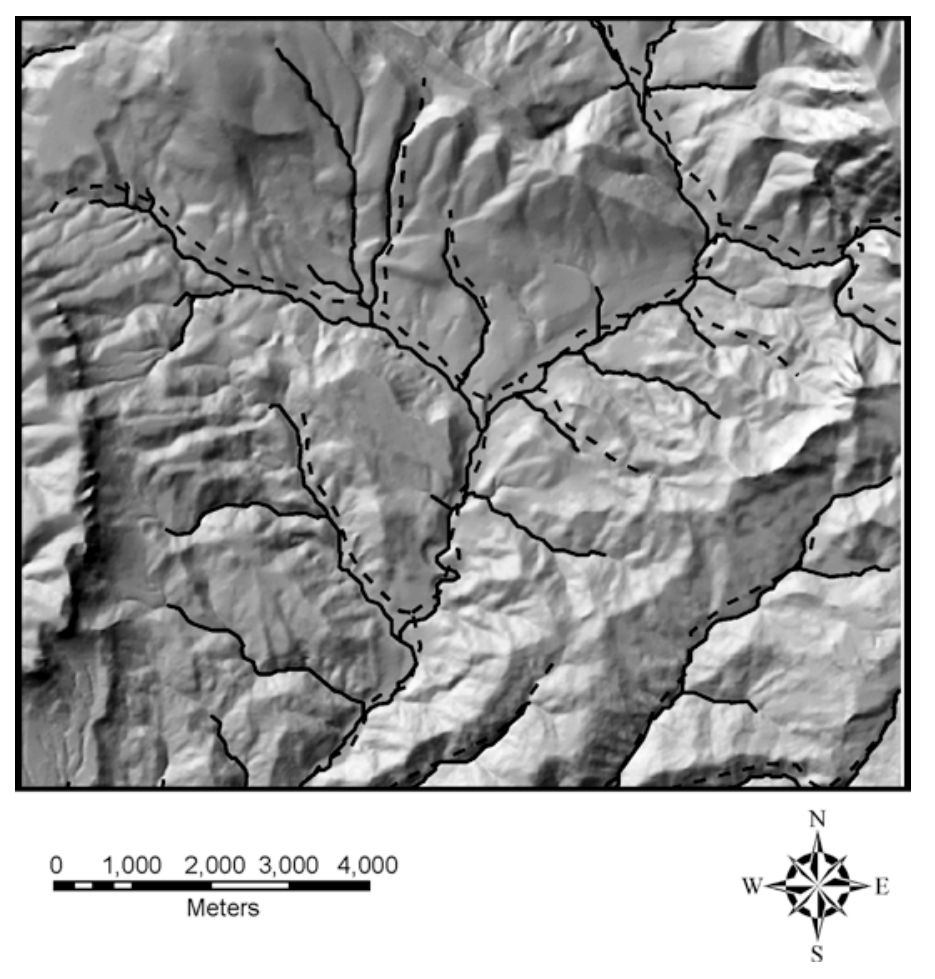


Figure 4.

A) Parcel map

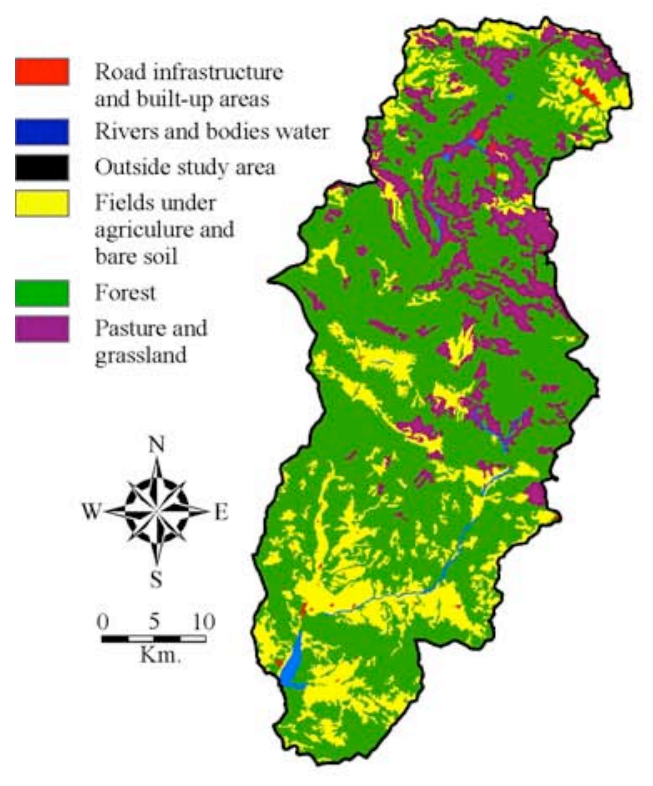

C) R-factor

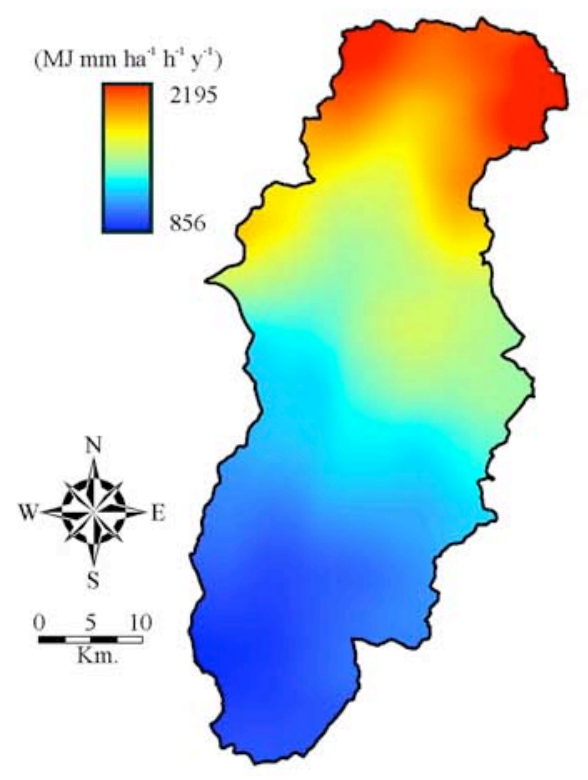

B) K-factor

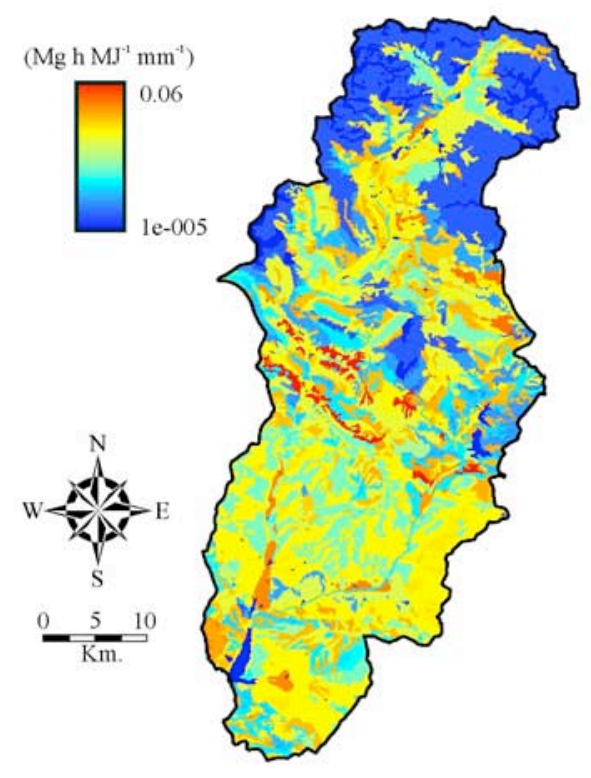

B) C-factor

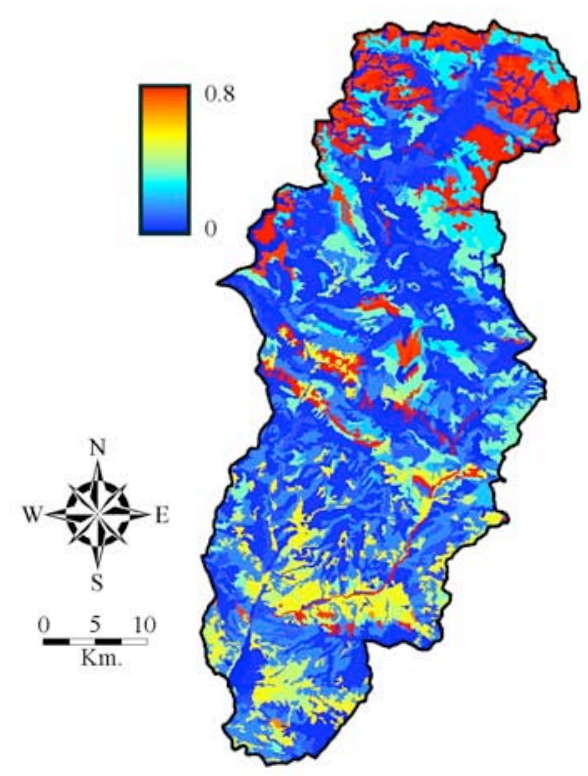


Figure 5
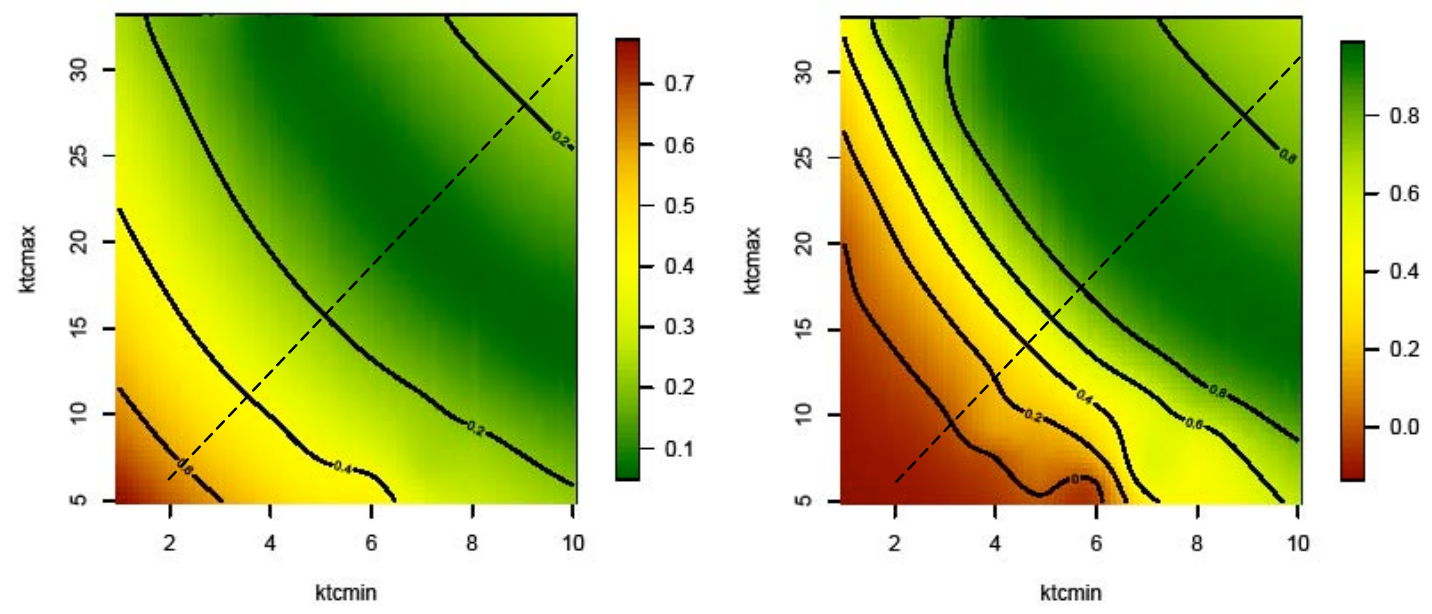
Figure 6.
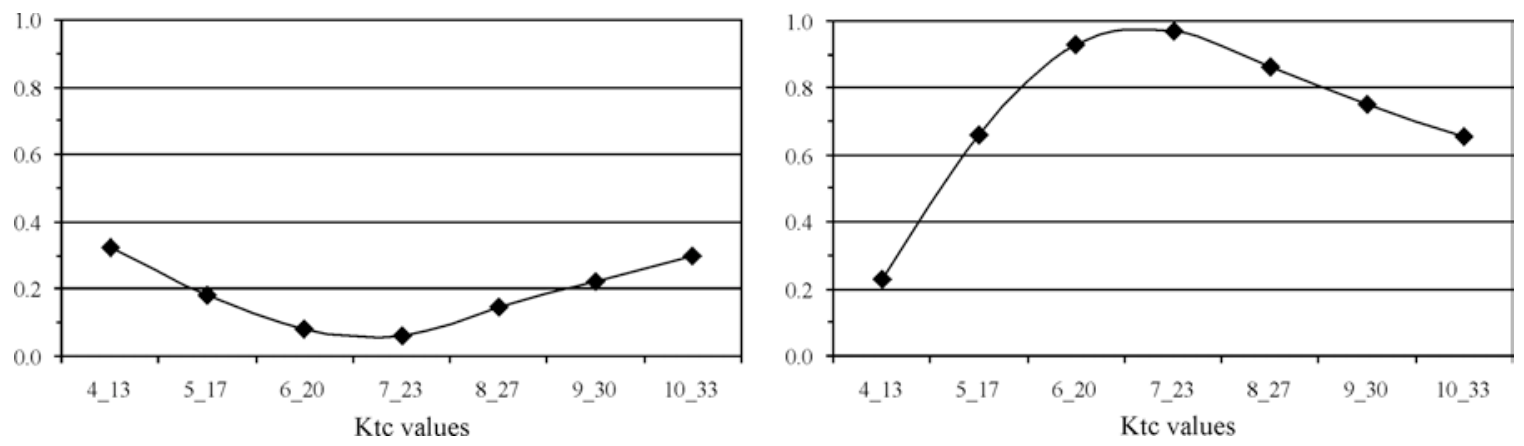
Figure 7.

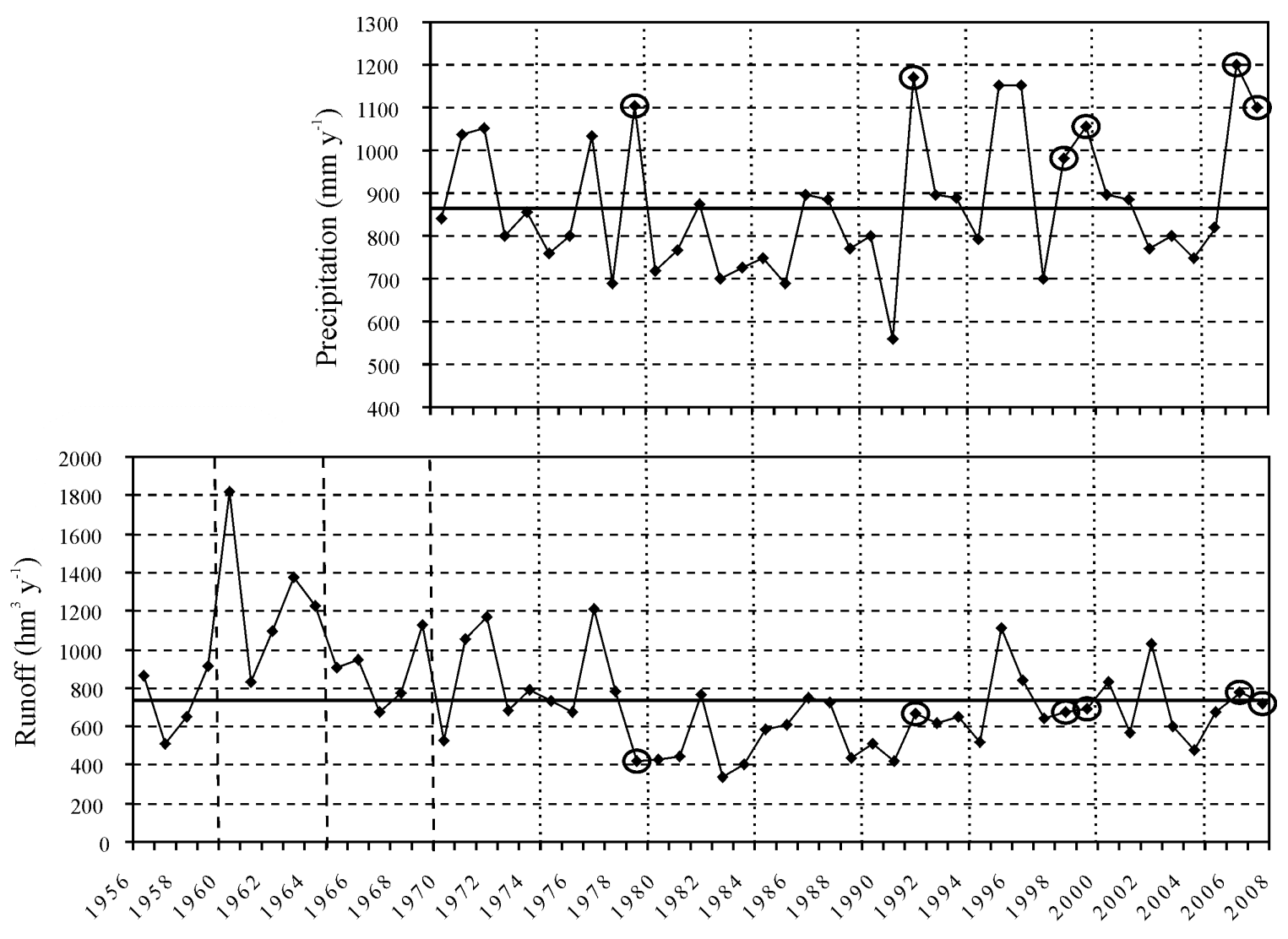


Figure 8.

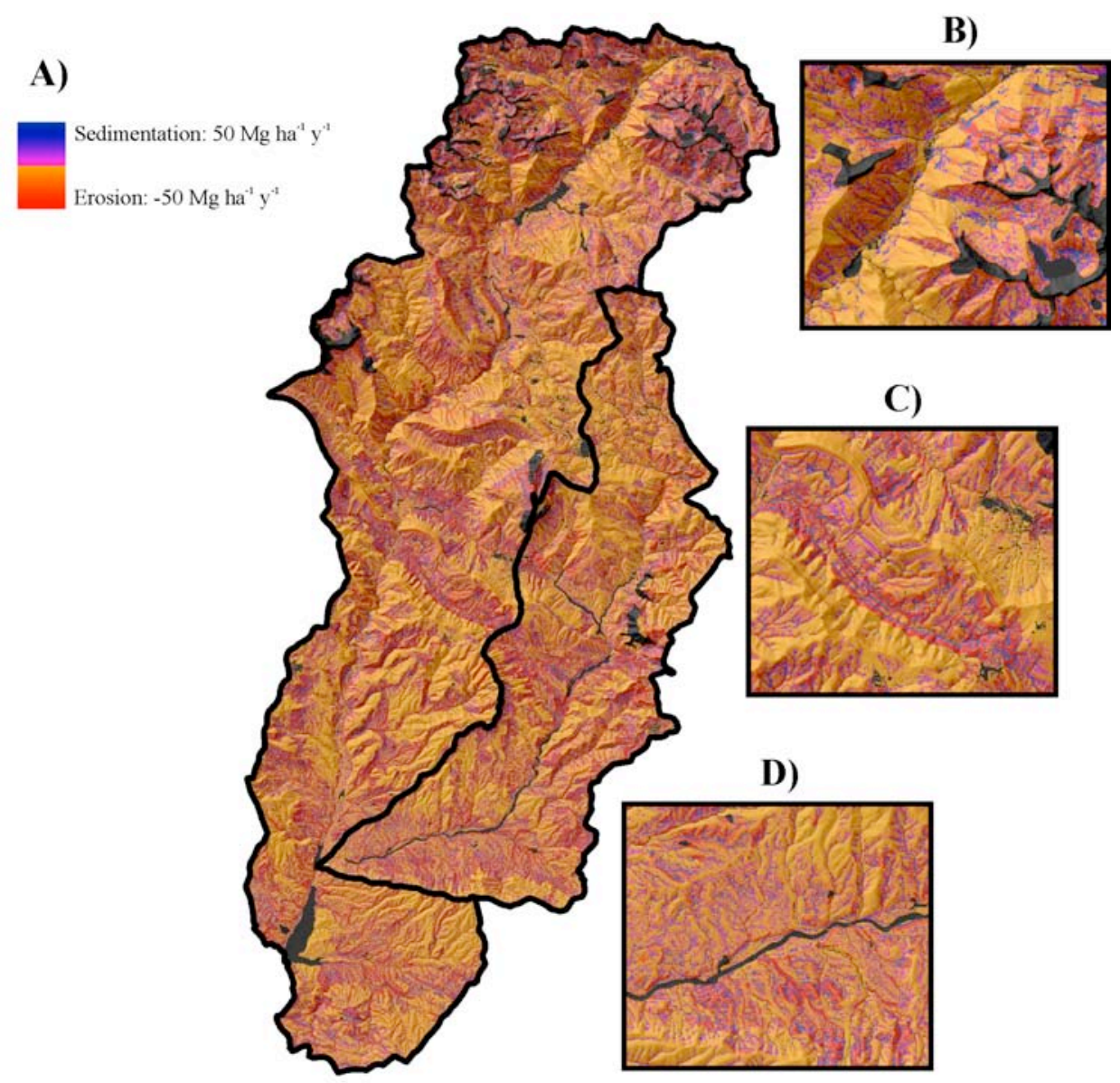


Figure 9.
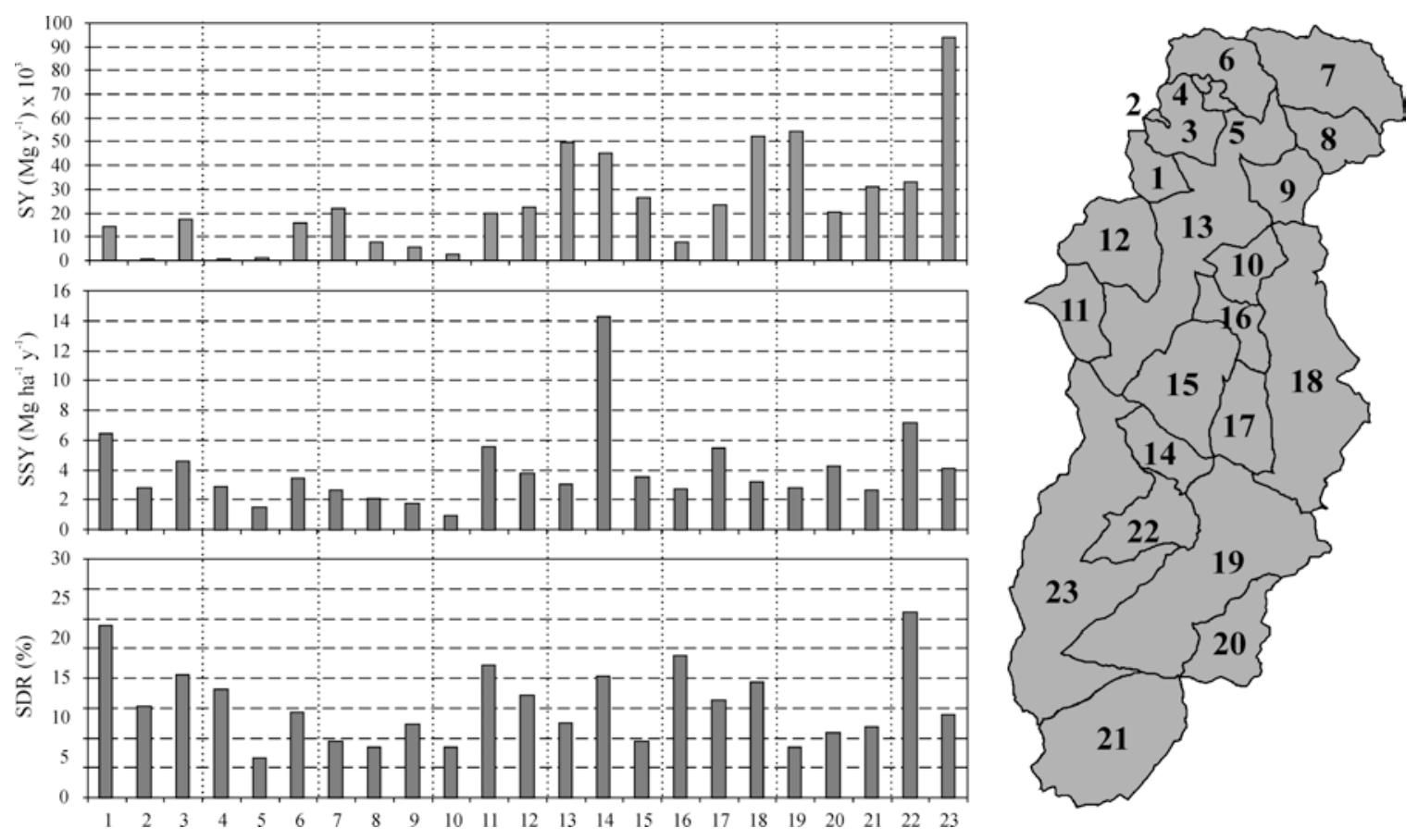
Figure 10.
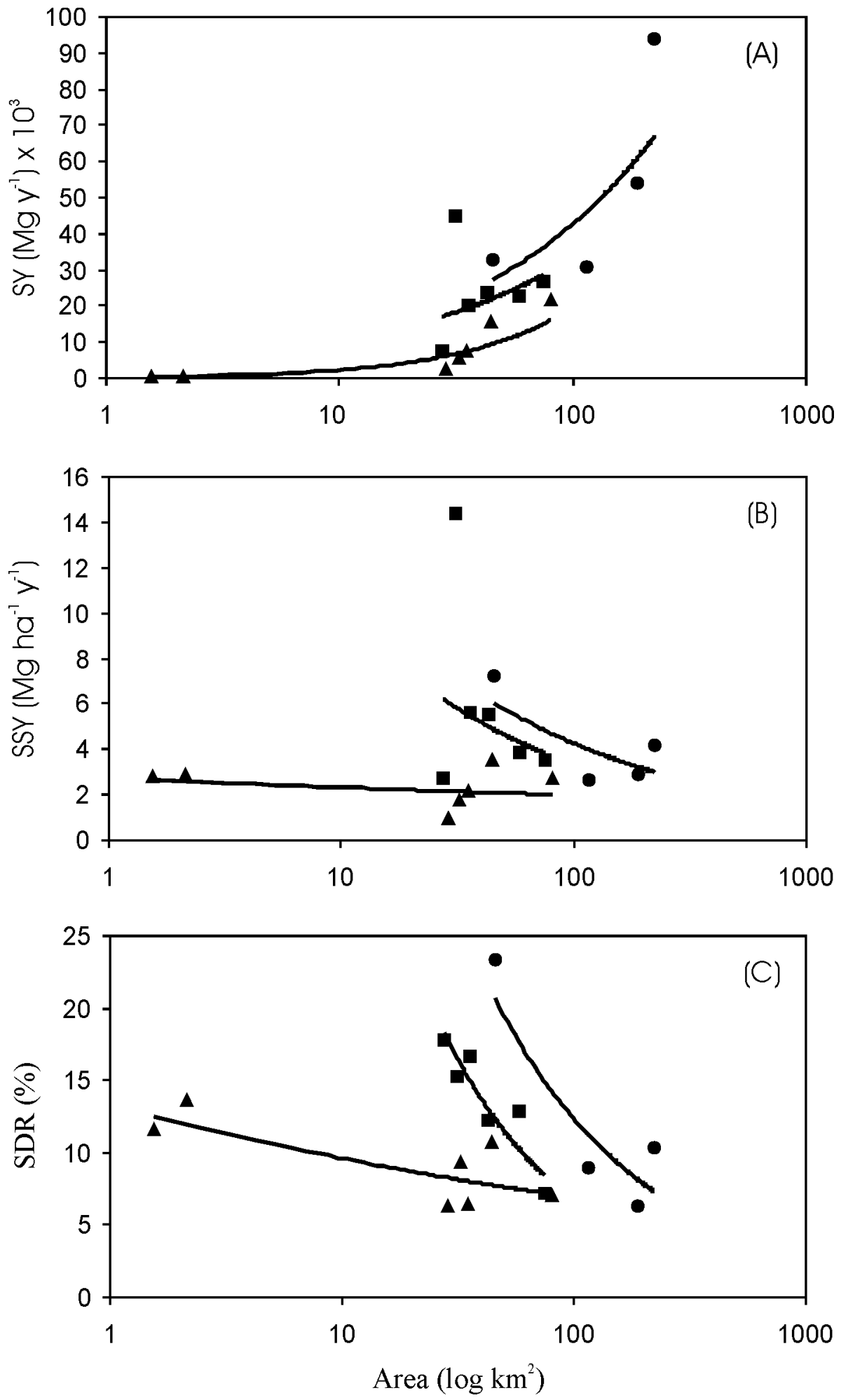